Scholarship Repository

University of Minnesota Law School

Articles

Faculty Scholarship

2010

\title{
The Law and Economics of Price Discrimination in Modern Economies: Time for Reconciliation?
}

\author{
Daniel J. Gifford \\ University of Minnesota Law School, giffo001@umn.edu \\ Robert T. Kudrle \\ University of Minnesota Hubert Humphrey Institute of Public Affairs, kudrle@hhh.umn.edu
}

Follow this and additional works at: https://scholarship.law.umn.edu/faculty_articles

Part of the Law Commons

\section{Recommended Citation}

Daniel J. Gifford and Robert T. Kudrle, The Law and Economics of Price Discrimination in Modern Economies: Time for Reconciliation?, 43 U.C. DAVIS L. REV. 1235 (2010), available at https://scholarship.law.umn.edu/faculty_articles/358.

This Article is brought to you for free and open access by the University of Minnesota Law School. It has been accepted for inclusion in the Faculty Scholarship collection by an authorized administrator of the Scholarship Repository. For more information, please contact lenzx009@umn.edu. 


\title{
The Law and Economics of Price Discrimination in Modern Economies: Time for Reconciliation?
}

\author{
Daniel J. Gifford* \\ Robert T. Kudrle* \\ TABLE OF CONTENTS \\ INTRODUCTION: LAWS TARGETING PRICE DISCRIMINATION ............. 1237 \\ I. ECONOMIC CONCEPTIONS OF PRICE DISCRIMINATION: \\ A BRIEF REVIEW ....................................................... 1239 \\ A. Price Discrimination, Defined .................................... 1239 \\ B. Arbitrage, Market Power, and Price Discrimination ........ 1243 \\ C. Price Discrimination Involving the Rates of Public \\ Utilities and Carriers........................................... 1247 \\ D. Price Discrimination by Multiple Firms ....................... 1250 \\ II. IDENTIFYING CONCERNS OVER PRICE DISCRIMINATION ......... 1255 \\ A. Revenue Generation, Welfare, and Competition .............. 1255 \\ B. Fairness.................................................................. 1255 \\ C. Efficiency and "Consumer" Welfare ........................... 1259 \\ III. LEGAL TREATMENT OF PRICE DISCRIMINATION IN THE \\ UNITED STATES ..................................................... 1260 \\ A. The Original Clayton Act ............................................ 1262 \\ B. The Robinson-Patman Act: Secondary-Line Effects ......... 1263 \\ C. Primary-Line Effects................................................ 1265 \\ D. Robinson-Patman Retrenchment .............................. 1269 \\ IV. PRICE DISCRIMINATION AND THE LAW IN THE EUROPEAN \\ UNION
A. Price Discrimination and Article 82(c) of the EC Treaty
B. Comparing Article 82(c) with the Robinson Patman Act .. 1276

* Robins, Kaplan, Miller \& Ciresi Professor of Law, University of Minnesota.

** Orville and Jane Freeman Professor of International Trade and Investment Policy, Hubert Humphrey Institute of Public Affairs and the Law School, University of Minnesota. 
C. Price Discrimination Beyond the Article 82(c) Context ... 1277

D. The Current Policy Frontier in the European Union and the United States: Loyalty Rebates

1. Single-Product Loyalty Rebates.............................. 1282

2. Multiproduct Loyalty Rebates (Bundled Rebates) ... 1288

V. PRICE DISCRIMINATION: AN OVERALl ASSESSMENT ................. 1292 


\section{INTRODUCTION: LAWS TARgeting PRICE DISCRIMINATION}

The practice of selling the same good at different prices -- generally referred to as price discrimination - has not fared well in the legal systems of modern economies. In the United States, the original Clayton $\mathrm{Act}^{1}$ and its later amendments attacked price discrimination. ${ }^{2}$ During the era of transportation regulation, various laws and regulations that governed railroad, motor vehicle, and air transport rates targeted price discrimination. ${ }^{3}$ In Europe, Article 82(c) of the European Community Treaty ("EC Treaty") assails price discrimination. ${ }^{4}$ The United States, the European Union, Canada ${ }^{5}$ and dozens of other rich and poor states also target price discrimination in international trade through antidumping and other trade laws. ${ }^{6}$

Why have the laws of the world's major economies attacked price discrimination? Is price discrimination the social evil that these laws appear to assume? This is not a new issue; economists and lawyers

1 Clayton Act, ch. $323, \S 2,38$ Stat. 730 (1914) (current version at 15 U.S.C. $\S 13$ (2006)).

2 Robinson-Patman Act of June 19, 1936, ch. 592, §§ 1-4, 49 Stat. 1526 (codified at 15 U.S.C. $\$ \S 13(\mathrm{a})$-(b), 21 a (2006)).

3 See Civil Aeronautics Act of 1938, ch. 601, 52 Stat. 973 (1938); Motor Carrier Act of 1935, ch. 498, 49 Stat. 543 (1935); Act to Regulate Commerce, ch. 104, 24 Stat. 379 (1887).

4 Treaty Establishing the European Community, art. 81(1)(d), 82(c), Nov. 10, 1997, 1997 O.J. (C 340) 3 [hereinafter EC Treaty]; see discussion infra Part V.

5 Section 50 of the Competition Act had criminalized price discrimination. Competition Act, R.S.C., ch. C-34, \& 50 (1985). Section 50, however, has recently been repealed. In the United States, the Antitrust Modernization Commission has recommended the repeal of the Robinson-Patman Act which also targets price discrimination.

6 Aradhna Aggarwal, Patterns and Determinants of Antidumping: A World-Wide Perspective 25-30 (Indian Council for Research on Int'l Econ. Relations, Working Paper No. 113, 2003), available at http://icrier.org/pdf/wp113.pdf. Before the 1990s, the United States, the European Union, Canada, and Australia have been the primary users of antidumping laws. Since the early 1990s, developing countries have begun to employ antidumping laws to protect their markets. In 1993, for example, antidumping laws were employed by Argentina, Brazil, India, Korea, Mexico, and South Africa. Christopher F. Corr, Trade Protection in the New Millennium: The Ascendancy of Antidumping Measures, 18 Nw. J. INT'L L. \& BuS. 49, 55-56 (1997); Wei Huo, Introduction and Critical Analysis of Antidumping Regime and Practice in China Pending Entry of WTO: Transition Toward a WTO-Modeled Trade Legal Mechanism, 36 INT'L LAW. 197, 198 (2002); Meredith Schutzman, Note, Antidumping and the Continued Dumping and Subsidy Offset Act of 2000: A Renewed Debate, 11 Cardozo J. INT'L \& COMP. L. 1069, 1077-78 (2004). 
have been concerned with price discrimination for decades. ${ }^{7}$ Economists tend to view price discrimination through the lens of welfare. ${ }^{8}$ For much of the twentieth century, antitrust lawyers typically assessed discrimination from a perspective of fairness. ${ }^{9}$ Since the antitrust "revolution" of the late $1970 s,{ }^{10}$ however, the focus of the antitrust bar has shifted. Now antitrust lawyers are beginning to view price discrimination as a species of competitive behavior. ${ }^{11}$ Indeed, the newer focus of the antitrust bar on discrimination as a manifestation of competition may provide a framework in which lawyers' concern for competition and economists' concern for welfare mesh into a common stance towards public policy.

This Article endeavors to sort out the various critiques of discriminatory pricing that have been made by lawmakers and economists, to assess the validity of these critiques, and to evaluate price-discrimination provisions contained in laws of the United States and the European Union. Part I briefly reviews some of the more

7 For example, the original Clayton Act $\S 2$ was enacted in 1914. As early as 1887, Congress enacted the Interstate Commerce Act condemning discrimination in railroad rates. The leading economic work on discrimination, Arthur $\mathrm{C}$. Pigou, The Economics of Welfare, was published in 1920. As pointed out below, Jules Dupuit was analyzing discrimination as a tool for paying for public works in the mid-nineteenth century. See generally Jules Dupuit, On Tolls and Transport Charges 7 (Int'l Econ. Papers No. 11, Elizabeth Henderson trans., 1962).

8 See Robert S. Pindyck \& Daniel L. Rubinfeld, Microeconomics 393-402 (7th ed. 2009).

9 See Corwin D. Edwards, The Price Discrimination Law 2-4 (1959); Paul Krugman, Reckonings: What Price Fairness? N.Y. TIMES, Oct. 4, 2000, at A35 ("[D]ynamic pricing [i.e., discriminatory pricing] is . . undeniably unfair."). Edwards distinguishes between a "political" and an "economic" understanding of price discrimination. The norm of equal treatment is a political idea upon which the Robinson-Patman Act is based. Economists, however, assess price discrimination from a perspective of its impact upon resource allocation.

10 John E. KWOKa \& LaWrence J. White, The Antitrust Revolution: ECONOMics, COMPETITION, AND POLICY 2-3 (1989).

11 See Antitrust Modernization COMm'N, RePort and ReCOMmendations 318-20 (2007), available at http:/govinfo.library.unt.edu/amc/report_recommendation/ chapter4.pdf. In addition, economists regularly contribute to antitrust law journals, bringing their perspectives into the legal mainstream. See, e.g., Jonathan B. Baker, Competitive Price Discrimination: The Exercise of Market Power Without Anticompetitive Effects, 70 AntrTRUst L.J. 643 (2003); William J. Baumol \& Daniel G. Swanson, The New Economy and Ubiquitous Competitive Price Discrimination: Identifying Defensible Criteria of Market Power, 70 ANTITRUST L.J. 661 (2003); Benjamin Klein \& John Shepard Wiley, Jr., Competitive Price Discrimination as an Antitrust Justification for Intellectual Property Refusals to Deal, 70 ANTITRUST L.J. 599 (2003); Benjamin Klein \& John Shepard Wiley, Jr., Market Power in Economiçs and in Antitrust: Reply to Baker, 70 ANTITRUST L.J. 655 (2003). 
prominent approaches taken by economists towards evaluating price discrimination. Part II proceeds to examine the main economic concerns that price discrimination raises. This Article then explores in some detail the relevant law and policy on the both sides of the Atlantic. Part III addresses the legal treatment of price discrimination in the United States, and Part IV discusses price discrimination laws in the European Union. This Article concludes by noting some continuing issues in price discrimination law and presents suggestions for their resolution.

\section{ECONOMIC CONCEPTIONS OF PRICE DISCRIMINATION: A BRIEF REVIEW}

Economists have examined price discrimination over the years with a somewhat different focus than those in the legal system. This Part considers the economic definition of price discrimination, its prerequisites, and the approaches that economists have taken towards analyzing price discrimination. There are two principal lines of price discrimination analysis relevant to this examination. The first line of analysis, starting with Jules Dupuit in the mid-nineteenth century, ${ }^{12}$ is concerned with the pricing of public utilities and carriers. The second, later and more general line of analysis begins with A.C. Pigou, who succeeded another dominant figure in economics, Alfred Marshall, to the chair in Political Economy at Cambridge University. ${ }^{13}$ Pigou developed a typology for examining the maximization of profits by adopting selling prices that vary based on purchaser or number of units sold. ${ }^{14}$ Pigou's typology has been widely employed by economists to demonstrate the variety of welfare effects that result from different types of price discrimination.

\section{A. Price Discrimination, Defined}

Although legal and common usage equates price discrimination with a price difference, ${ }^{15}$ economists usually attach a different meaning to price discrimination. When economists use the term, they mean that two or more similar goods are being sold at prices that bear different

12 See generally Dupuit, supra note 7.

13 R. H. Coase, The Appointment of Pigou as Marshall's Successor, 15 J.L. \& ECON. 473,473 (1972).

14 See Arthur C. Pigou, The Economics of Welfare 282 (1920).

15 FTC v. Anheuser-Busch, Inc., 363 U.S. 536, 549 (1960) ("[A] price discrimination ... is merely a price difference."); see also Texaco, Inc. v. Hasbrouck, 496 U.S. 543, 558-59 (1990). 
ratios to their marginal costs. ${ }^{16}$ The Robinson-Patman Act takes the simpler, common usage view that a price difference is price discrimination, ${ }^{17}$ but also considers costs in determining whether a violation has occurred. This cost-justification defense makes otherwise prohibited discrimination lawful when the price difference does not exceed the difference in cost. ${ }^{18}$ Corwin Edwards explained the sources of these two views on price discrimination, noting that the economic view of price discrimination was rooted in the concern that goods and services be allocated to their highest valued uses. ${ }^{19}$ The then-prevailing legal view, which Edwards describes as a "political" one, was rooted in the concept of equal treatment. ${ }^{20}$ The contrast between these two approaches to price discrimination is significant.

The classic analysis of price discrimination involves action by a monopolist to enlarge profits by dividing the market so that each buyer or class of buyers pays a price closer to the buyers' reservation prices - the maximum price the buyer is willing to pay - than would otherwise be the case. Although even the most experienced seller in a primitive market such as a Levantine souk cannot "size up" his customers well enough to remove all consumer surplus, this example is useful to probe a priori prejudices about price discrimination. Is the merchant "unfair" by pricing as he does? Assuming that the buyer is assessing the product's personal value accurately, is she being cheated by paying as much as she is willing to pay? What if you knew that the merchant was earning only a normal rate of return on his skills? That the superiority of modern fixed pricing is based mainly on efficiency is an unavoidable fact. Individual bargaining is simply too costly in terms of valuable time to survive for most transactions in high-income societies. This Article argues that instead of "fairness" concerns, other concerns - such as efficiency

16 George J. Stigler, The Theory of Price 209 (1966).

1715 U.S.C. \& 13 (2006). In FTC v. Anheuser-Busch, Inc., the Supreme Court construed the language of that Act as equating price discrimination with a price difference. 363 U.S. at 549.

1815 U.S.C. \& 13(a). The focus of the Robinson-Patman Act is thus on absolute values (i.e., whether the absolute value of the cost differences equal or exceed the price differences), while economists focus on ratios (i.e., whether the price/cost ratios are the same). In fact, Lars Stole has avoided this problem with his recent definition: "Price discrimination exists when prices vary across customer segments that cannot be entirely explained by variations in marginal cost." LARS A. STOLE, PRICE DISCRIMINATION AND IMPERFECT COMPETITION 1 (2003), available at http://web.mit.edu/ 14.271/www/hio-pdic.pdf.

19 Corwin EdWards, The Price Discrimination LaW 1-5 (1959).

20 Id. 
and the fact that different purchase prices (relative to cost) mean that goods are not allocated to maximize welfare - should underlie antipathy towards price discrimination. ${ }^{21}$

In The Economics of Welfare, A.C. Pigou identified three categories of price discrimination and assessed their effects: first-degree, seconddegree, and third-degree price discrimination. ${ }^{22}$ First-degree price discrimination involves charging every customer the maximum amount they are willing to pay for each unit of the product sold. This removes all "consumer surplus," the usual excess of value that people get from buying multiple units of a good at a fixed price. In theory and, if perfectly carried out, however, first-degree price discrimination would generate no deadweight loss. ${ }^{23}$ First-degree discrimination can only be roughly approximated and only occurs in specialized circumstances.

Second-degree price discrimination is the practice of setting two or more prices for a good, depending on the amount purchased. The most familiar variant is the two-part tariff where there is an entrance fee into the market followed by a single price for all units purchased. Two- or multi-part pricing is often used to increase output in a regulated monopoly, while allowing total costs to be covered by total revenues. Buyers typically do not all face the same price for marginal purchases under second-degree price discrimination, however, and this generates allocative inefficiencies. For example, if there are two or more prices, one for a set of initial units and a lower charge or charges for succeeding blocks, not everyone has sufficient demand to get past the first high price range. Additionally, increasingly rightward demand curves are likely to confront successive lower prices, implying that not everyone adjusts purchases to the same marginal price. As a result, goods are not allocated to their highest valued uses.

In third-degree price discrimination, a seller identifies separable market segments, each of which possesses its own demand for its product. The seller then sets a price for each segment in accordance with that segment's demand elasticity. Joan Robinson demonstrated that a monopolist's output remains constant with linear demand

21 The most widely accepted benchmark for antitrust - at least for noneconomists - is the consumer surplus standard, and it rests on a notion of fairness: that only the welfare of buyers (and not sellers) counts. As a practical matter, however, it diverges only seldom from the total surplus standard.

22 Pigou, supra note 14 , at 275-89.

23 A deadweight loss results in situations in which price and marginal cost are not equated. 
curves whether or not the monopolist discriminates. ${ }^{24}$ Further, she notes that under third-degree discrimination, output is misallocated by comparison with sales at a single monopoly price; the latter is superior in welfare terms. She also discovered that, when demand is not linear, output will expand when the more elastic of the two markets is relatively convex (to the origin). ${ }^{25}$ This implies that under discrimination, overall welfare can improve only if output expands enough to outweigh the inefficiency of different marginal prices when sales occur in both markets at the simple monopoly price. When the "weaker" more elastic market is not served at that price, however, discrimination increases welfare even with linear demand curves. This is because discrimination in this case leaves the "stronger" market unchanged and output expands in the "weaker" market, and there is no uniform price at which the seller would choose to serve the second market. Because the relative demand elasticities of different markets vary, no further general propositions about the welfare effects of thirddegree price discrimination are possible.

Richard Schmalensee refined Robinson's criterion for output expansion when both markets are served under discrimination. Professor Schmalensee concluded that, combined with the result that discrimination could lead to a weak market being served that would otherwise not be, "[i]f one thinks that demand functions are as likely to be concave as convex, recognition of this effect would lead one to conclude that total output is more likely to be increased than decreased by allowing a monopoly to practice third-degree discrimination." ${ }^{26}$ But Professor Schmalensee then immediately

\footnotetext{
24 JOAN ROBINSON, THE ECONOMICS OF IMPERFECT COMPETITION 188-95 (1933).

25 Her precise criterion for overall output expansion, "the adjusted concavity ratio," however, was not satisfactory. See E.O. Edwards, The Analysis of Output Under Discrimination, 18 ECONOMETRICA 163, 163 (1950) (describing "slope ratio" as alternative criterion to "adjusted concavity"); Richard Schmalensee, Output and Welfare Implications of Monopolistic Third-Degree Price Discrimination, 71 AM. ECON. REV. 242, 242 (1981) (generalizing and extending Robinson's main results using algebraic approach). When the aggregate demand curve in the linear case is established by adding two (or more) curves linearly, increased profitability requires that average revenue from discrimination must be greater than average revenue from simple monopoly. But the aggregate marginal revenue curve has twice the slope of the aggregate demand curve and its position depends only on a constant times total output. When demand is not linear, however, the position of the aggregate marginal revenue is no longer so simply determined. It is now a function not only of the total output across both (all) submarkets but of terms that contain the volume of sales in the individual markets; hence its intersection with marginal cost is not independent of the shapes of the individual demand curves.
}

26 Schmalensee, supra note 25 , at 245. 
demonstrates that output expansion is only a necessary but not a sufficient condition for welfare expansion; output must expand more in the weak market that it contracts in the strong one because each unit is more highly valued in the latter. ${ }^{27}$

\section{B. Arbitrage, Market Power, and Price Discrimination}

Price discrimination is entirely dependent on the infeasibility of arbitrage, but less so on the level of a seller's market power. Arbitrage occurs when buyers in the low-priced market resell in the high-priced market. To the extent that arbitrage is feasible, it would eventually bring the price levels of the different markets to the same level. In so doing, arbitrage would route the goods involved to their highestvalued users, thereby eliminating an inefficiency connected with discrimination and increasing welfare. Further, as arbitrage narrowed the difference between prices in the two markets, it would also be eroding the profitability of discriminatory selling. When prices in the two markets reached the same level, price discrimination would no longer be possible. Arbitrage is impractical or difficult when the good involved is not easily resold (as has been the case, until recently, for electricity), and arbitrage is generally impossible for most kinds of services. Similarly, there can be no arbitrage when the cost of transportation from one market to another (or other impediments) exceeds the price differential.

The terms "market power" and "monopoly power," are central to legal considerations about price discrimination, but their varying definitions have led to much confusion. Abba Lerner offered an early definition of monopoly power that focused attention on the common characteristic of sellers in imperfect competition: monopoly power is some power over price. ${ }^{28}$ Whenever a firm faces a downwards sloping demand curve for any reason, it possesses power over price, which, in Lerner's usage, is monopoly power. Lerner's measure inversely relates to the elasticity of demand, the index falling as demand elasticity increases. Thus, Lerner's monopoly power exists whenever a seller markets a differentiated product, regardless of the number and volume of competing goods and regardless of the firm's profits or short-run losses. ${ }^{29}$ The Lerner index, of course, will be lower as the firm's

\footnotetext{
27 Id. at 246.
}

28 A.P. Lerner, The Concept of Monopoly and the Measurement of Monopoly Power, 1 REV. ECON. STUD. 157, 169 (1934).

29 Profit is the difference between total cost and total revenue, and marginal cost bears no dependable relation to average or total cost. 
competition increases because the demand for its product will become increasingly elastic. ${ }^{30}$

The article in which Lerner presented this definition appeared several years after the publication of Edward Chamberlin's The Theory of Monopolistic Competition. ${ }^{31}$ Chamberlin analyzed the effects of competition, first among a substantial number of rivals offering heterogeneous products, ${ }^{32}$ and second among a smaller group of rivals also selling heterogeneous products. ${ }^{33}$ Most economists today reserve the term "monopolistic competition" for Chamberlin's large group whose sellers typically lack substantial power over price. ${ }^{34}$ Lerner presumably used the term monopoly power because he wanted to stress the widely varying relation that can exist between prices and marginal costs across monopoly, oligopoly, and monopolistic competition. ${ }^{35}$ Except for the definitional zero-profit condition of the third structure, the Lerner index allows for any level of profitability in the long run. Monopolies and oligopolies are not always profitable. But Lerner was not concerned in this article with policy towards profits, a central focus of industrial organization economists and lawyers.

Even though Lerner employed the term monopoly power to refer to all situations in which price exceeds marginal cost, others have used that term differently. A leading industrial organization textbook, for example, uses monopoly power to refer to situations of supra-normal profits, while employing market power to describe firms that only break even. ${ }^{36}$ Still others employ monopoly power to refer to the

30 Thus, while Lerner employed the language of "monopoly power," he was providing a measure of the degree of that power. See Gregory J. Werden, Demand Elasticities in Antitrust Analysis, 66 ANTITRUST L.J. 363, 372 (1998).

31 EdWARD H. Chamberlin, The Theory OF MONOPOlistic COMPETITION (1933).

32 Id. at 81-100.

33 Id. at 100-04.

${ }^{34}$ As he employed the term, Chamberlin's small group is an oligopoly selling differentiated products. CHAMBERLIN, supra note 31 , at 100 . "Monopolistic competition" currently refers to an industry "in which there are a large number of firms producing similar but not identical products." MIT DICTIONARY OF MODERN ECONOMICs 285 (David W. Pearce ed., 3d ed. 1986).

35 The very term monopolistic competition as commonly used isolates price inelasticity as the "monopolistic" element and zero long-run profits as the "competitive" element.

36 Dennis W. Carlton \& Jeffrey M. Perloff, Modern Industrial Organization 93 (4th ed. 2004). After setting forth their distinction between monopoly power and market power, the authors observe that "people do not always make this distinction, and generally use the two terms interchangeably, sometimes creating confusion." Id. As if to verify the latter point, the same textbook later uses the term "market power" in the 
power of a seller controlling the entire supply of a good, and market power to refer to a significant power over price, even though less than that possessed by a firm controlling the entire supply. In fact, market power is the term used by a majority of competition policy economists to describe the target of their efforts. ${ }^{37}$

Most competition policy aims to limit significant market power characterized by supernormal profitability. ${ }^{38}$ Profitability, in turn, is simply the difference between total revenue and total cost denominated by some measure of invested capital considered over a certain period. If average total cost equals marginal cost, the Lerner index would accurately gauge relative profitability across industries if the ratio of total sales to owners' investment does not vary. Not only does this ratio vary greatly, however, industries also vary enormously in the ratio of variable to fixed or sunk cost. Moreover, at any given time, short-run marginal cost may be above or below its long-run value, so any simple use of the ratio of price to marginal cost as an index of profitability can be completely misleading. Nonetheless, the Lerner index relates to profitability in this way: the reciprocal of the Lerner index is demand elasticity, and less elastic demand leads to a higher profitability.

Monopoly power, which in ordinary language might suggest a stronger version of market power, is still widely used by economists in precisely the way Lerner originally used it and may refer to situations that are utterly innocuous from a policy point of view. ${ }^{39}$ Conversely, monopoly power suggests something stronger than market power, especially in the antitrust caselaw. ${ }^{40}$ Einer Elhauge points out that

context of policy interventions that clearly aim at supernormal profits. Id. at 643 .

37 See Lawrence J. White, Market Power and Market Definition in Monopolization Cases, in Issues in COMPetition Law And Policy 913, 917 (Wayne D. Collins ed., 2008).

38 The "performance" part of the original Harvard "structure, conduct, performance" approach to competition policy was very concerned with price-cost margins and sometimes attempted to use firm profitability as a rough index of them. See Joe S. Bain, The Profit Rate as a Measure of Monopoly Power, 55 Q.J. ECON. 271, 288 (1941).

39 The "Lerner Index of Monopoly Power" is presented in virtually all intermediate price theory texts. For example, PINDYCK \& RUBINFELD, supra note 8, at $363-65$, illustrates the caveat that the ratio of price to marginal cost is a very poor guide to profitability because it ignores fixed (and previously-expensed sunk) cost. In sharp contrast, monopoly power is generally reserved in legal discourse to refer to firms possessing very strong market power and an implication of high profits. RICHARD A. Posner, Antitrust Law 195 ( $2 \mathrm{~d}$ ed. 2001).

40 See, e.g., Eastman Kodak Co. v. Image Technical Servs., Inc., 504 U.S. 451, 481 (1992) ("Monopoly power under $\$ 2$ [of the Sherman Act] requires ... something 
while the courts may effectively use the term monopoly power as involving a "significant" or "substantial" degree of market power, market power under section one is "normally defined as not just any ability to raise prices above competitive levels but an ability to raise prices 'substantially' over those levels." ${ }^{41}$ Elhauge concludes: "We are thus left with a standard that defines itself as requiring a substantial degree of a sort of power that is itself defined to exist only when substantial. This builds vagueness upon vagueness." ${ }^{42}$ In still other instances, writers apparently use the terms monopoly power and market power interchangeably. ${ }^{43}$

The confusion grows when one considers price discrimination in the context of a firm's power over price and its profitability. Judge Richard Posner, for example, recently referred to the association between price discrimination and profitability, writing:

Price discrimination implies market power, that is, the power to charge a price above cost (including in "cost" an accounting profit equal to the cost of equity capital) without losing so much business so fast to competitors that the price is unsustainable. The reason price discrimination implies market power is that assuming the lower of the discriminatory prices covers cost, the higher must exceed cost. ${ }^{44}$

Unfortunately, while Posner uses market power as most industrial organization economists do, his statement is misleading because it assumes that the lower price of a discriminating seller must cover cost. It must at least cover marginal cost, but need not exceed average total cost. Profitability results only when the revenue generated by total sales (including both sales at the lower and higher price levels) exceeds total costs (including fixed or sunk costs). Price discrimination increases the seller's revenue - otherwise he would not engage in discrimination - but nothing guarantees that a seller's

greater than market power under § 1."). Gregory Werden states that "[c]ircuit courts have commonly distinguished 'market power' from 'monopoly power' as a matter of degree, and the Supreme Court has used the two terms in essentially this manner." Werden, supra note 30 , at 378 .

41 Einer Elhauge, Defining Better Monopolization Standards, 56 STAN. L. REV. 253, 258-59 (2003).

42 Id. at 259.

43 PINDYCK \& RUBINFELD, supra note 8 , at $340 \& \mathrm{n}$. 1 . These and other writers use market power to refer to both monopoly and monopsony power where both concern power over price and not profitability.

44 In re Brand Name Prescription Drugs Antitrust Litig., 186 F.3d 781, 783 (7th Cir. 1999). 
maximum revenue exceeds its total costs. Because there is no necessary association between price discrimination and profitability, it is not surprising that even unprofitable firms can practice discrimination, though only in the short run. ${ }^{45}$ Moreover, the market power requisite to practicing price discrimination can be exceedingly low. ${ }^{46}$ Given that sellers in most commercial markets face downward sloping demand curves for their products, it is probably accurate to say that (so long as arbitrage can be controlled), price discrimination is possible in most markets. Indeed, as the discussion below shows, economists have come to see that price discrimination can be a principal instrument of competitive behavior.

\section{Price Discrimination Involving the Rates of Public Utilities and Carriers}

Much of the early analysis of price discrimination focused on the charges of public utilities and carriers and how to generate sufficient revenues to cover fixed costs while maximizing production valued at equal to or greater than marginal cost. The central problem faced by regulators in public utility pricing was how to generate sufficient revenues to cover all of the utility's costs while otherwise keeping those charges to a minimum. ${ }^{47}$ In the many years over which scholars have addressed the problem of maximizing welfare subject to a no-loss constraint, some form of price discrimination has been the answer.

In the mid-nineteenth century, Jules Dupuit, who supervised the inspection of French bridges and highways, focused much of his attention on the use of discrimination as a means for increasing both usage and toll revenues from these public works. ${ }^{48}$ His focus, which was upon the use of discrimination as a means for inducing greater usage of the industry's product, led him to view what Pigou would later characterize as first-degree discrimination as the ideal. ${ }^{49}$ Because

45 James C. Cooper et al., Does Price Discrimination Intensify Competition? Implications for Antitrust, 72 ANTITRUST L.J. 327, 341 (2005).

46 Elhauge, supra note 41 , at 258 ("IT] he price discrimination normally taken to evidence market power is so ubiquitous that it would indicate market power exists everywhere."); see also Baumol \& Swanson, supra note 11, at 661-66.

47 This assumes that when marginal cost equals marginal benefit, total benefit also exceeds total cost; this condition is typically met.

48 This description of Dupuit is drawn primarily from Robert Ekelund's commentary. See Robert B. Ekelund, Jr., Price Discrimination and Product Differentiation in Economic Theory: An Early Analysis, 84 Q.J. ECON. 268, 269-71 (1970); see also Baumol \& Swanson, supra note 11, at 671.

49 For definition of the degrees of Pigovian discrimination, see infra. 
of the difficulties in implementing first-degree discrimination, however, Dupuit opted for the use of third-degree price discrimination as the vehicle by which to increase output and enhance welfare..$^{50}$

Later in the nineteenth century, F.W. Taussig concluded that because most costs of a railroad are joint costs that cannot be allocated to any particular shipped commodity, railroad pricing is almost necessarily based upon the varying elasticities of demand of the commodity shippers. ${ }^{51}$ So long as the rate for a particular commodity exceeded the marginal costs attributable to that particular commodity, the rate would be set at the level that the traffic would bear (i.e., at the profit-maximizing price for that commodity) and the excess over marginal cost would contribute to the coverage of the railroad's fixed costs. $^{52}$ Thus, Taussig concluded that a discriminatory pricing schedule was required for a railroad in order to cover its overall costs. Pigou challenged Taussig's cost analysis but came to a similar conclusion about pricing. ${ }^{53}$ F.P. Ramsey addressed the problem of meeting a revenue constraint with the most efficient set of charges in $1927 .{ }^{54}$ Ramsey's analysis - now widely employed by public-utility regulators ${ }^{55}$ - indicates that welfare will be maximized subject to the condition that revenues cover the utility's costs, if rates are set on each class of customers in inverse proportion to the demand elasticity of that customer class. The Interstate Commerce Commission practiced a version of regulated pricing prior to railroad deregulation in the United States, ${ }^{56}$ and variants of Ramsey pricing are also widely practiced in Europe. ${ }^{57}$

The natural monopoly problem can also be addressed by Pigovian second-degree price discrimination such as the "two-part tariff," which involves a lump-sum entry fee plus another charge for each unit

50 Ekelund, supra note 48, at 271.

51 F.W. Taussig, A Contribution to the Theory of Railway Rates, 5 Q.J. ECON. 438, 443-44 (1891).

52 Id.

53 Arthur C. Pigou, The Economics of Welfare 290-317 (4th ed. 1932).

54 Frank P. Ramsey, A Contribution to the Theory of Taxation, 37 ECON. J. 47, 47 (1927).

55 See William J. Baumol \& J. Gregory Sidek, Toward Competition in local TELEPHONY 35-42 (1994); Jim Rossi, Universal Service in Competitive Retail Electric Power Markets: Whither the Duty to Serve?, 21 ENERGY L.J. 27, 35 (2000) (describing regulators reliance on Ramsey pricing).

56 Robert B. Wilson, Non-Linear Pricing 98 \& n.2 (1993).

57 See, e.g., Marcel Boiteux, On the Management of Public Monopolies Subject to Budgetary Constraints, 3 J. ECON. THEORY 219 (1971) (explaining operationalization of optimal pricing subject to budget constraint). 
purchased. Such pricing could eliminate the inefficiency resulting from different marginal prices for different buyers (which characterize Ramsey pricing), but only if the first charge is set low enough not to exclude a significant number of potential purchasers. Moreover, all publicly regulated prices are subject to political influence, and the potential of devices such as two-part pricing are often totally lost as a result. For example, telephone subscribers typically pay a charge for connection to the network and pay rates keyed to their use of the telephone service. Yet the connection cost frequently is less than the telephone company's marginal cost of establishing the connection (especially in new residential or commercial developments in outlying areas), and the use charges generally exceed the marginal cost of usage, inefficiently discouraging use and subsidizing connection charges. ${ }^{58}$ Whether actual regulation employing non-linear pricing typically increases or decreases welfare relative to feasible alternatives is not clear.

In summary, one can usefully divide the economic literature on the welfare effects of price discrimination under monopoly between unregulated and regulated outcomes. Price discrimination by unregulated private monopolies is most appropriately benchmarked by comparison with a situation in which such behavior is either banned or infeasible. An increase in output provides a necessary condition for social improvement that, if sufficiently small, might be overbalanced by the negative welfare effects resulting from all consumers not facing the same marginal prices if third degree price discrimination is practiced. A consumer surplus standard would judge the two situations by whether consumer surplus increases a more stringent test. Substantial social gain from third-degree discrimination by both measures results from a weaker market served under discrimination with no change in the stronger one. And it is even possible that there could be no output at all without third-degree price discrimination. For example, prior to the widespread development of medical insurance, if a doctor in an isolated rural area could not charge more to the rich and less to the poor, he might not have been able to earn a normal return on his own (mainly human) capital, and no medical services would have been offered at all..$^{59}$

58 Alfred E. Kahn, The Road to More Intelligent Telephone Pricing, 1 YALE J. ON REG. $139,141-42$ (1984).

59 This is an unregulated result that closely resembles Ramsey pricing. 


\section{Price Discrimination by Multiple Firms}

Although the welfare effects of price discrimination by both regulated and unregulated monopolies deserve attention, monopoly sellers are only a small part of all economies. Most price discrimination everywhere results from competition against other firms. It is therefore necessary to determine when this enhances social welfare and when it does not.

Although Robinson, Schmalensee, and Hal R. Varian ${ }^{60}$ added considerably to Pigou's treatment of third-degree monopoly price discrimination, the formal analysis of multi-firm markets did not appear until quite recently. Severin Borenstein used simulation to demonstrate some suggestive results, ${ }^{61}$ and T.J. Holmes developed the first complete analytic presentation of an important special case. ${ }^{62}$

If identical members of an oligopoly engage in lock-step "monopoloid" behavior, the outcomes are trivial variants of the monopoly case. Instead, Holmes investigates the case of a differentiated duopoly of a particularly simple kind: although the outputs of each firm are by assumption not identical, their costs and demands within each of two markets are conveniently treated as being the same.$^{63}$ Holmes assumes Bertrand competition, that is, each firm sets its price on the assumption that the price of the other firm is fixed. Although the model is very simple, the range of possible outcomes is so broad as to provide virtually no guide for policy intervention. For example, Holmes demonstrates that optimal firm price depends on both overall market demand and intra-market crosselasticity. ${ }^{64}$ Differing intra-industry cross-elasticities across submarkets might overbalance differences in industry elasticity for the combined outputs of the firms at identical prices. This means that when cross-elasticities between the firms differ sufficiently between the two markets, the price-cost margin can be higher in the aggregately weaker market producing a price ordering that would be the reverse of what would be established by a discriminating

60 See ROBINSON, supra note 24, at 188-95; Schmalensee, supra note 25 , at 242; Hal R. Varian, Price Discrimination and Social Welfare, 75 AM. ECON. REV. 870, 870 (1985).

61 Severin Borenstein, Price Discrimination in Free Entry Markets, 16 RAND J. ECON. 380, 389-94 (1985).

62 Thomas J. Holmes, The Effects of Third Degree Price Discrimination in Oligopoly, 79 AM. ECON. REV. 244, 244-50 (1989).

63 CHAMBERlin, supra note 31 , app. $H$, at 314-15.

64 Holmes establishes that the elasticity of demand facing each firm in each submarket is the inverse of the sum of (1) the industry elasticity of demand and (2) the cross-elasticity of demand between the firms. Holmes, supra note 62 , at 245-46. 
monopolist, although all prices would still be lower in both markets than would be the case under monopolistic price discrimination. These complications add to those resulting from ambiguity in output change with nonlinear demand under discriminating monopoly. Therefore, even granting the other simplifying assumptions, only a detailed knowledge of demand conditions in specific submarkets would allow a confident judgment about the welfare impact of price discrimination.

Holmes's model was a great advance, yet most patterns of actual discriminatory pricing rest on conditions at variance with his assumptions. For example, K.S. Corts relaxes the assumption that each firm faces the same cross-price elasticity within each submarket. ${ }^{65}$ As Holmes anticipated, this can change everything. ${ }^{66}$ Firms in a duopoly, for instance, may have differing views about which is the strong and which is the weak market, and this could lead to lower prices in both submarkets. Unfortunately, for those seeking robust guidance for policy design, the same logic suggests that discrimination could lead to all prices rising. But Corts demonstrates that if not every firm in an oligopoly regards the same submarket as stronger, "there is the potential for unilateral incentives toward more aggressive behavior in each individual market for some firm, and if the strategic complementarily of such aggressive pricing is strong enough, prices may fall in every market." ${ }^{\text {67 }}$ Although their models are different, both Holmes and Corts suggest situations in which discrimination can lower the profits of both or all firms, and those firms would therefore favor constraints that prevent discrimination across submarkets. ${ }^{68}$

Monopoly models of all kinds share a great advantage in simply assuming overall "industry" demand without trying to explain it. ${ }^{69}$ The advantage remains when monopoly is replaced by simply posited duopoly or oligopoly. But in applying models, identifying the range of relevant actors on both sides of the markets is often not obvious. For example, in one scenario Corts considers a set of sellers discriminating temporally through periodic sales, which, in turn, intensifies competition with firms that sell similar goods at consistently lower

65 Kenneth S. Corts, Third-Degree Price Discrimination in Oligopoly: All-Out Competition and Strategic Commitment, 29 RAND J. ECON. 306, 307 (1998).

66 Holmes, supra note 62, at 250.

67 Corts, supra note 65 , at 321 .

68 See id.; Holmes, supra note 62, at 249.

69 See, e.g., PindYCK \& RUBinfeld, supra note 8, at 349-72 (employing abstract models involving sole producer of unidentified "product"). 
prices. ${ }^{70}$ The introduction of the periodic sales drives down the prices of the consistently cheaper firms still further. In the real world, the number, aggregate market share, and cohesion of the set of firms engaging in such temporal third-degree price discrimination as well as the number, share, and cohesion of their consistently lower priced rivals would likely vary greatly across geographic markets.

The academic literature establishes definite welfare results for price discrimination only for a small set of well-defined cases that in general, would be hard to identify in the real world. ${ }^{71}$ In addition, as soon as one tries to marry any insight from formal models with the facts of actual situations, the specific context in such dimensions as seller cohesion and entry conditions adds so much complication that the application of special theoretical insights appears to be almost a matter of faith. This may be particularly true where markets separate spatially with a varying set of established firms playing the role of best-placed potential entrants, a typical situation not just within national markets but also as characteristics of increasing "globalization." Such potential participants may induce price restraint in tacitly collusive oligopoly, and, when and if entry takes place, may diminish the previous level of effective cohesion on a range of behaviors including price setting.

The economic literature suggests that, absent sufficient entry and sufficiently intense price competition, many counterintuitive and seemly perverse results are possible. ${ }^{72}$ Price discrimination can lower welfare in some circumstances, but this does not leave one undecided about policy. The law should view the possibility of harm from price discrimination with greater skepticism than it presently does. For example, Judge Posner is famous for having observed that "[t]he purchaser to whom the discriminating seller sells at a lower price may be no more efficient than the competing purchaser who is charged a higher price." ${ }^{" 73}$ This formal possibility does not provide a good basis

70 Corts, supra note 65, at 308-09.

71 See, e.g., id. (relating formal models to actual competitive situations); Varian, supra note 60 (describing progress of scholarship in identifying conditions where price discrimination will increase aggregate welfare).

72 In a recent survey of price discrimination and oligopoly by Stole, see generally STOLE, supra note 18 , a wide variety of models are developed including those that allow for entry. Far more often than not, whether price discrimination increases or lowers welfare depends on parameter values in a way that is difficult to summarize; the survey offers discouragingly little in the way of policy-relevant generalizations.

73 PoSNER, supra note 39, at 203. Part of Posner's objection to price discrimination also derives from his continuing concern that increased monopoly profits lead to greater social waste generated by attempts to appropriate them. Not only has this 
for policy, because there is no evidence that equally efficient retailers have often been harmed by discrimination, or that final output has diminished.

M.L Greenhut and H. Ohta, leading scholars of spatial competition, note that:

[A] laissez-faire approach in place of anti-trust restrictions on spatial pricing would allow firms to select the price policy that conforms best to the market conditions to which they are subject. Ceteris paribus, output would be maximized under the spatial price policy that happens to maximize the profits of the representative firm. ${ }^{74}$

Economists writing on price discrimination from an empirical perspective usually stress the use of discrimination as a welfareimproving competitive weapon. For instance, Corts admits the possibility of negative results, but he emphasizes in conclusion: "Competitive price discrimination may intensify competition by giving firms more weapons with which to wage their war. Allowing firms to set market-specific prices through discrimination breaks the crossmarket profit implications of aggressive price moves that may restrain price competition when firms are limited to uniform pricing." 75 And, while acknowledging the possibility of other results, Daniel O'Brien and Greg Shaffer attack the Robinson-Patman Act by stressing the pervasiveness of bargaining in intermediate good markets and the consequently misleading models that ignore this reality. They argue that forbidding price discrimination "constrains the bargaining process by inhibiting buyers from seeking marginal price concessions that lower retail prices." 76

For decades, economists have recognized that oligopolistic pricing is likely to foster secret price-cutting. For example, in his seminal 1964 article on oligopoly, Nobel prize-winner George Stigler presented a theory tying the vulnerability of oligopolistic pricing to the marketshare dispersion of its members because small sellers can cheat with less chance of detection. ${ }^{77}$ As Stigler argued, oligopolistic pricing

hypothesis not been treated kindly by economists, but assumptions informing his discussion ignore the role of discrimination in rapidly changing markets - just the problem considered in much of the literature.

74 M.L. Greenhut \& H. Ohta, Output Effects of Spatial Price Discrimination Under Conditions of Monopoly and Competition, 46 S. ECON.J. 71, 83 (1979).

75 Corts, supra note 65 , at 321

76 Id. at 314.

77 George J. Stigler, A Theory of Oligopoly, 72 J. POL. ECON. 44, 47 (1964). 
breaks down when members depart from the target pricing levels that its members have tacitly agreed upon. While it is in the collective interest of its members to maintain the oligopolistic price, each of its members has an incentive to increase its profits by increasing its own sales, if it can do so without immediately undermining the oligopoly. In any particular case, therefore, the question is whether an oligopolist can reduce its price in order to make an attractive sale while keeping information about its price-cutting from the other members of the oligopoly.

Stigler also points out that sellers tend to seek out larger, rather than smaller, purchasers for the selective price cuts that will expand their volume while minimizing the possibility of detection by other members of the oligopoly. If the probabilities of detection for any one undercutting sale are approximately the same, those sellers who concentrate their sales efforts on larger buyers maximize the ratio of their sales volume to the risk of detection. An attempt to obtain the same volume by sales to smaller buyers would increase the chances of detection exponentially ${ }^{78}$ The result is that smaller buyers generally pay more to oligopolistic sellers than do larger buyers. In Stigler's words:

It follows that oligopolistic collusion will often be effective against small buyers even when it is ineffective against large buyers. When the oligopolists sell to numerous small retailers, for example, they will adhere to the agreed-upon price, even though they are cutting prices to larger chain stores and industrial buyers. ${ }^{79}$

Stigler presents a case in which practices that disadvantage smaller resellers serve the general welfare. Such selective price cutting is a mechanism through which the behavior of sellers, seeking to expand their profits, is likely to lead to a general reduction in the price level. Antitrust policy, therefore, should encourage that practice.

William Baumol and Daniel Swanson argue that not only is price discrimination compatible with competition, but that in industries characterized by high fixed costs - especially industries characterized by repeated high-fixed-cost investments - competition would compel producers to engage in differential pricing. ${ }^{80}$ This practice parallels the familiar predicament of some unregulated utilities and carriers facing the necessity to raise sufficient revenue to cover their fixed costs.

\footnotetext{
78 Id.

79 Id.

80 Baumol \& Swanson, supra note 11, at 661-62.
} 
When arbitrage is impossible, third-degree price discrimination is a way of increasing revenue relative to cost - that is of increasing profit. Baumol and Swanson point out that when such industries are characterized by intense competition, each firm is likely to find its price structure under intense downward pressure resulting in each firm engaging in price discrimination across "distinct and non-trade compartments" but earning zero profits in the long run. ${ }^{81}$ In this special case, the invisible hand produces an outcome similar to Ramsey pricing.

\section{IDENTIFYING CONCERNS OVER PRICE DISCRIMINATION}

\section{A. Revenue Generation, Welfare, and Competition}

As discussed above, during the century before World War II economists focused on price discrimination as a technique for enlarging monopoly profits generally and as means by which capitalintensive utilities and carriers could cover their fixed costs. In fact, it is likely that elite opinion in the West concluded that price discrimination was legitimate only under public control. This certainly seems to have been the dominant view among lawyers until quite recently. Careful economists, however, have always considered increasing the size of the pie (greater efficiency) and the allocation of its pieces (equity) separately. Both second- and third-degree price discrimination can often increase efficiency; first degree is seldom feasible. Moreover, economists developed special cases in which all prices could fall under discrimination or rise only for the relatively well off, so both efficiency and dominant views of equity could sometimes be satisfied at once. ${ }^{82}$ This was all prologue to the consideration of discrimination in multiple firm contexts. When economists confronted price discrimination as an element of competitive strategy, they found a wide range of possible outcomes in which such behavior both increased efficiency and lowered prices for final purchasers. The fate of those other than producers and final purchasers, however, also required consideration.

\section{B. Fairness}

Even as economists examined the effects of price discrimination on welfare, lawyers were assessing its fairness. Indeed, lawyers - and the

81 See id. at 665.

82 See RoBINSON, supra note 24 , at 203-08; STOLE, supra note 18 , at 17-23. 
public at large - tended to view price discrimination in terms of fairness, at least since the late nineteenth century ${ }^{83}$ When Congress responded to the agitation of farmers and others with legislation prohibiting the railroads from discriminating in their hauling charges, it described the practice of discrimination as unfair ${ }^{84}$ During the early twentieth century particularly, lawyers tended to focus upon the disadvantages faced by business firms that paid more for a product than their rivals. Congress again perceived this disadvantage as "unfair." 85

During this same period, lawyers tended to reinforce their intuitive sense of unfairness with norms drawn from the operation of competitive markets. ${ }^{86}$ Under those norms, price discrimination was unfair, because, in addition to intuitive reasons, it was inconsistent with the conditions that would characterize a perfectly operating competitive market, where all purchasers would pay the same price for any given product. ${ }^{87}$ Additionally, a widely shared view among lawyers was that the antitrust laws incorporated fairness norms, ${ }^{88}$ most of which were inferred from competitive market operations, as explained above. ${ }^{89}$ Thus, business firms that possessed the power to discriminate

83 See Ian Ayres, Market Power and Inequality: A Competitive Conduct Standard for Assessing When Disparate Impacts Are Unjustified, 95 CAL. L. REv. 669, 681 (2007); James Boyle, Cruel, Mean, or Lavish? Economic Analysis, Price Discrimination and Digital Intellectual Property, 53 VAND. L. REv. 2007, 2038 (2000); Daniel A. Farber \& Brett H. McDonnell, Why (and How) Fairness Matters at the IP/Antitrust Interface, 87 MiNN. L. REV. 1817, 1868-70 (2003).

${ }^{84}$ See, e.g., New York, New Haven \& Hartford R.R. Co. v. Interstate Commerce Comm'n, 200 U.S. 361, 391 (1906) ("[T]he great purpose of the act to regulate commerce ... was to secure equality of rates to all, and to destroy favoritism ....").

${ }^{85}$ Thus, the House report on $\S 2$ of the Clayton Act spoke of discrimination (albeit predatory discrimination) as unfair. H.R. REP. No. 63-627, at 8-9 (1914); see also Charles G. Haines, Efforts to Define Unfair Competition, 29 YALE L.J. 1, 2 \& n.4 (1919).

86 See Carl Kaysen \& Donald F. Turner, Antitrust Policy: An Economic and LEGAL ANALYSIS 16 (1959). Writing at mid-century, these antitrust scholars recognized that one understanding of "fairness" was based upon "the character transactions would have if they took place in competitive markets." Id. at 56 . They also identified that "competitive processes provide one standard by which fair business conduct can be defined." Id. at 16.

87 See Pindyck \& Rubinfeld, supra note 8, at 8-9; see also M. A. Adelman, Price Discrimination as Treated in the Attorney General's Report, 104 U. PA. L. REV. 222, 224 (1955).

88 See KAYSEN \& TURNER, supra note 86 , at 56 (" 'Fair dealing' as a standard of business conduct is now and historically has been an important element of antitrust law.").

89 See id. at 45-46; see also Eyal Zamir, The Efficiency of Paternalism, 84 VA. L. REV. 229, 246 (1998) (describing competitive-market model). 
were perceived as acting both anticompetitively and unfairly. For example, Standard Oil Company's practice of selling at higher prices in some geographic markets than in others was condemned as both anticompetitive and unfair..$^{90}$

Congress also equated unfairness with anticompetitive behavior as justification for the antidumping laws of that period. When Congress enacted antidumping laws, it portrayed its legislation as directed against unfair practices. ${ }^{91}$ Legislators probably believed that German chemical and steel cartels were selling at monopoly prices in their home market and at marginal-cost prices in the United States, ${ }^{92}$ and it viewed those practices as "unfair" to domestic manufacturers..$^{93}$ Indeed, the antidumping laws continue to be directed towards ensuring that foreign goods are sold at "fair value" in the United States. ${ }^{94}$ This concern, moreover, was emphasized in the Tariff Act of 1922, which contained provisions directed against "unfair methods of competition and unfair acts in the importation of articles into the United States." ${ }^{95}$ The unfair methods of competition and unfair acts included dumping, i.e., international price discrimination. ${ }^{96}$ References to "fairness" in trading relationships continue to this day to permeate public discourse about trade legislation. ${ }^{97}$ This is not surprising, because all interest groups seek to cast their positions in favorable language, and it has been easy for protectionist interests to describe their position in the language of fairness.

The treatment of price discrimination in international trade law essentially abandons concern for domestic welfare completely, and focuses exclusively on the welfare of domestic producers. Laws against "dumping" use some measure of the home market prices of foreign sellers as benchmarks, forbidding the foreign sellers from pricing below those benchmarks. Even if dumping might be beneficial to a

\footnotetext{
90 H.R. REP. No. 63-627, at 9; S. Rep. No. 63-698, at 3 (1914).

91 H.R. REP. No. 66-479, at 1 (1919) (describing pending antidumping legislation as direct against "discriminations and unfair practices from abroad").

92 See U.S. TARIFF COMm'N, InFORMATION CONCERNING DUMPING AND UNFAIR Foreign COMPETITION IN THE UNITED STATES AND CANADA'S ANTIDUMPING LaW 14 (1919); Daniel J. Gifford, Rethinking the Relationship Between Antidumping and Antitrust Laws, 6 AM. U. J. INT'L L. \& POL'Y 277, 306-07 (1991).

93 See Gifford, supra note 92 , at 299-300.

94 See 19 U.S.C. \$ 1673(1) (2006).

95 Tariff Act of 1922, ch. 356, \& 316(a), 42 Stat. 943 (1922). These provisions are now contained in 19 U.S.C. \& 1337 (a)(1)(A) (2006).

96 Gifford, supra note 92, at 295.

97 J. Michael Finger, The Meaning of "Unfair" in United States Import Policy, 1 MinN. J. Global TRAdE 35, 40 (1992); Gifford, supra note 92, at 301.
} 
market as a whole, it will object where dumping disadvantages its producers ${ }^{98}$ Such a market's purchasers, however, gain more than the producers lose..$^{99}$ When there is a problem of predatory pricing in a specific market, a state's competition laws should attack such behavior. Widespread imitation of American legislation has resulted in similar laws in most modern and many developing countries. ${ }^{100}$ "Antidumping" is an element of trade law that essentially turns competition policy on its head, ${ }^{101}$ and such laws should be abandoned as soon as politically feasible, in which case they will almost certainly be bargained, rather than given, away.

Like international trade measures and laws directed against international price discrimination, for its first eighty years antitrust legislation was associated with issues of "fairness." 102 Indeed, in the antitrust context, the rhetoric of competition and fairness had often blended. Normal competitive behavior was seen as fair and thus opposed to monopolistic behavior, which was seen as unfair. The

${ }_{98}$ The first U.S. antidumping act defined dumping as the sale of goods in the United States at prices lower than those prevailing in the seller's home market. Antidumping Act of Sept. 8, 1916, ch. 463, \& 801, 39 Stat. 798, repealed by Pub. L. $108-429$, tit. 2 , \& 2006(a), 118 Stat. 2434 (2004). Current antidumping law defines dumping as sales in the United States at prices below the home market price and sales in the United States at below-cost prices. 19 U.S.C. \& 1677-1(b) (2006).

99 See, e.g., RichaRd E. CAVES ET AL., WORLD TRADE AND PAYMENTS: AN INTRODUCTION 236-38 (10th ed. 2007).

100 See Karl M. Meessen, Europe En Route to 1992: The Completion of the Internal Market and Its Impact on Non-Europeans, 23 INT'L LAw. 359, 369 (1989); Nadia E. Nedzel, Antidumping and Cotton Subsidies: A Market-Based Defense of Unfair Trade Remedies, 28 Nw. J. INT'L L. \& Bus. 215, 223, 243 (2008) (observing that “developing countries are now initiating more antidumping measures than are developed countries").

101 Robert Lipstein argues that moving some "dumping" procedures closer to those used for the Robinson-Patman Act would be an improvement (though he disapproves of both). See generally Robert A. Lipstein, Using Antitrust Principles to Reform Antidumping Law, in Global COMPETITION POLICY 405 (E.M. Graham \& J.D. Richardson eds., 1997). Our argument applies equally to "countervailing duties" that allegedly protect domestic producers from low prices due to foreign government intervention. In both cases, as Milton Friedman so memorably put it, "we should just smile and say 'thank you.' " Third-degree price discrimination does not, of course, lead to maximum welfare worldwide. But those with high prices, not low prices, have the national interest incentive to fix the problem. And they can do so by discovering why arbitrage into their markets fails to erase any price differences not based on differing cost.

102 See KAYSEN \& TURNER, supra note 86 , at 16-17, 89-91 (discussing "fairness" as antitrust concern); see also F. Scott Kieff \& Troy A. Paredes, The Basics Matter: At the Periphery of Intellectual Property, 73 GEO. WASH. L. Rev. 174, 184 \& n.29 (2004) (describing roles played by fairness and other concerns in early antitrust history). 
Federal Trade Commission Act in 1914 explicitly incorporated the language of fairness, when, in section five, Congress prohibited unfair methods of competition. ${ }^{103}$ Similarly, in the early twentieth century, observers often viewed the Sherman Act's strictures against monopolization as protections against big business treating small businesses unfairly. ${ }^{104}$

Lawyers' historical preoccupation with fairness issues generated by price discrimination provided them with a very different perspective than economists, who were instead concerned with the welfare effects of discrimination. The respective vocabularies of lawyers and economists reflect these different perspectives. Traditionally, the terms "welfare" or "aggregate welfare" have not been part of the legal vocabulary. Until the antitrust revolution of the $1970 \mathrm{~s},{ }^{105}$ when the furtherance of "consumer welfare" was recognized by the courts as the ultimate goal of antitrust law, the closest analogue in the professional vocabulary of lawyers to the economist's welfare had been perhaps the "public interest." The term public interest, however, lacks the precision of the term welfare, and is less amenable to quantification. Not surprisingly, even today government officials and politicians frequently refer to the public interest but rarely to welfare or aggregate welfare. The rhetoric of fairness that lawyers and officials have employed also carries a potential for obscuring the tension between the desires of politically active constituents and their lobbyists on the one hand, and the interests of the mass of citizens on the other. Indeed, goals that can plausibly be described as fair often reduce aggregate welfare.

\section{Efficiency and "Consumer" Welfare}

After the antitrust revolution of the late 1970s, the focus of the American antitrust bar shifted from fairness to efficiency. ${ }^{106}$ Today, fairness has largely disappeared as a factor in antitrust analysis. Because welfare is maximized as efficiency is maximized, the new focus of the antitrust bar on efficiency necessarily is also a focus upon welfare, if only by implication. ${ }^{107}$ As a result, the antitrust bar now

103 Federal Trade Commission Act, ch. 311, § 5, 38 Stat. 717 (1914) (current version at 15 U.S.C. \& 45 (2006)).

104 See Rudolph J. Peritz, Competiton Policy in AMerica 1888-1992: History, RHETORIC, LAW 40, 64-65 (1996).

105 See KWOKA \& WHITE, supra note 10 , at $1-5$.

106 Id. at 4-5.

107 Aggregate welfare is maximized when the sum of allocative and productive efficiencies is maximized. When antitrust law fosters net efficiency, therefore, it 
largely approaches price discrimination from an efficiency or welfare perspective ${ }^{108}$ This shift moves legal practitioners closer to economists in assessing the impact of price discrimination. As economists shift their focus away from a static analysis of price discrimination by a monopolist towards the dynamic effects of discrimination in competitive settings, the orientation of lawyers and economists are beginning to converge.

Despite this shift, however, things are not quite so simple. Antitrust practitioners, academic lawyers, and the courts now widely refer to efficiency as the ultimate norm - courts also have repeatedly stated the ultimate goal of antitrust law as the furtherance of consumer welfare. ${ }^{109}$ The legal use of this latter phrase, however, is ambiguous. For example, Robert Bork equates consumer welfare with efficiency and aggregate welfare by equating "consumers" with everyone, including both narrowly defined consumers and producers. ${ }^{110}$ Yet many courts appear to use the phrase consumer welfare in the narrower, more familiar sense, equating it, in the analysis of particular transactions, with the surplus of final purchasers, or consumer surplus. In the European Union, the consumer surplus standard completely dominates the aggregate welfare standard. ${ }^{111}$

\section{LEgal TREATMENT OF PRICE Discrimination IN THE UNITED STATES}

Lawmakers respond to the demands of their constituents, especially those who have organized effectively and can exert the greatest political pressures. ${ }^{112}$ This, and the then prevalent belief that price discrimination was unfair, largely explains why Congress was wary of

fosters aggregate welfare. See Alan Devlin \& Bruno Peixoto, Reformulating Antitrust Rules to Safeguard Societal Wealth, 13 STAN. J.L. BUS. \& FIN. 225, 259 (2008); Yedida Z. Stern, A General Model for Corporate Acquisition Law, 26 J. CORP. L. 675, 678 (2001).

108 See Joseph F. Brodley, The Economic Goals of Antitrust: Efficiency, Consumer Welfare, and Technological Progress, 62 N.Y.U. L. Rev. 1020, 1020 (1987) (describing these goals and making recommendations for achieving them).

109 Reiter v. Sonotone Corp., 442 U.S. 330, 343 (1979); see Daniel J. Gifford \& Robert T. Kudrle, Rhetoric and Reality in the Merger Standards of the United States, Canada, and the European Union, 72 ANTITRUST L.J. 423, 428 (2005).

110 See Robert H. Bork, THe ANTitrust Paradox 107-08 (1978) (including benefit to producers resulting from cost reduction as adding to consumer welfare).

111 See Gifford \& Kudrle, supra note 109 , at 424 . As a practical matter, the two criteria lead to differing policy conclusions in only a very few cases.

112 See, e.g., Mancur Olson, The Theory of Collective Action: Public Goods and THE THEORY OF GROUPS (1971) (presenting most influential rational choice model showing importance of concentrated interests for political efficacy). 
price discrimination when it enacted the Interstate Commerce Act in 1887. ${ }^{113}$ Responsiveness to a broad base of constituents, the perceived unfairness of price discrimination, and the long-held view that price discrimination was itself anticompetitive behavior, explains why Congress enacted an array of laws condemning that practice. The Interstate Commerce Act prohibited rail carriers from engaging in "unjust" discrimination, which it equated with charging shippers different amounts for similar service. ${ }^{114}$ Congress was responding to widespread dissatisfaction with discriminatory railroad rates, dissatisfaction pressed by farmers' organizations throughout the 1870 s and by manufacturing and commercial interests in the $1880 \mathrm{~s} .{ }^{115}$ The farmers complained that railroads were imposing higher charges when they had no competition than when competition existed. ${ }^{116}$ In response to these complaints, numerous states enacted antidiscrimination legislation directed at the railroads, but the Supreme Court in 1886 invalidated such legislation. ${ }^{117}$ Congress responded by enacting the Interstate Commerce Act the following year. Even at this early date, a connection between price discrimination and monopoly was part of the public consciousness. From a political point of view, discrimination appeared to document monopoly by presenting a clear benchmark against which to compare exploitatively higher charges. ${ }^{118}$ Much of the farmers' concern would have remained if all producers of the same commodity faced the same transport prices. The so-called Granger Movement, which resulted in anti-price discrimination legislation in a number of states, already manifested the political power of farmers. ${ }^{119}$ Numerous regulatory acts followed the Interstate

113 See Interstate Commerce Act, ch. 104, §§ 1-2, 24 Stat. 379 (1887) (current version at 49 U.S.C. $\$ 10101(6)$ (2006) (proscribing reasonable rate requirement)); see also id. \& 10101(12) (prohibiting discrimination by rail carriers).

114 Interstate Commerce Act \& 2 (prohibiting unjust discrimination); see also id. \& I (prohibiting "every unjust and unreasonable charge").

115 See Solon J. Buck, The Granger Movement 230 (1913).

116 See id. at 14-15.

117 See Wabash, St. L. \& Pac. Ry. v. Illinois, 118 U.S. 557, 575 (1886).

118 If the differing prices resulted from differing strength of competition, the benchmark would be more meaningful than if differing pricing were based on differing elasticities of user demand ("value of service" pricing). In the latter case, banning discrimination would increase low prices as it lowered high ones.

119 See Buck, supra note 115, at 123-205 (describing legislation, inter alia, in Illinois, Minnesota, Iowa, Wisconsin, Missouri, Nebraska, Kansas, Califomia, and Oregon). 
Commerce Act, many of which contained analogous provisions prohibiting unjust discriminations in the rates charged. ${ }^{120}$

\section{A. The Original Clayton Act}

In 1914, Congress passed the Clayton Act, which addressed price discrimination generally in $\S 2 .{ }^{121}$ Responding to complaints about the behavior of the Standard Oil Company and the American Tobacco Company, ${ }^{122}$ Congress prohibited discrimination in prices where the effect was likely to lessen competition or tend toward monopoly. Committee Reports from both the House and Senate describe these companies as having been engaging in behavior now called predatory pricing. ${ }^{123}$ These Reports also asserted that these companies were supporting their predatorily-low prices in some markets from monopoly revenues that they were earning in other markets. ${ }^{124}$ Scholars have since pointed out that this congressional understanding was flawed and that the companies probably were not in fact acting predatorily. ${ }^{125}$ Congress addressed discrimination again in the Antidumping Act of $1916 .{ }^{126}$ In that legislation, and in subsequent

120 See, e.g., Motor Carrier Act of 1935, ch. 601, § 202, 49 Stat. 543 (1935); Civil Aeronautics Act of 1938, ch. 601, §2(c), 52 Stat. 977 (1938).

121 Clayton Act, ch. 323, § 2, 38 Stat. 730 (1914) (current version at 15 U.S.C. § 13 (2006)).

122 See H.R. REP. No. 63-627, at 8-9 (1914):

The necessity for legislation to prevent unfair discriminations in prices with a view of destroying competition needs little argument to sustain the wisdom of it. In the past it has been a most common practice of great and powerful combinations engaged in commerce - notably the Standard Oil Co., and the American Tobacco Co., and others of less notoriety, but of great influence - to lower prices of their commodities, oftentimes below the cost of production in certain communities and sections where they had competition, with the intent to destroy and make unprofitable the business of their competitors, and with the ultimate purpose in view of thereby acquiring a monopoly in the particular locality or section in which the discriminating price is made. Every concern that engages in this evil practice must of necessity recoup its losses in the particular communities or sections where their commodities are sold below cost or without a fair profit by raising the price of this same class of commodities above their fair market value in other sections or communities.

Identical language is found in the Senate Report. S. REP. No. 63-698, at 2-4 (1914).

123 See H.R. ReP No. 63-627, at 9; S. REP. No. 63-698, at 3.

124 H.R. REP No. 63-627, at 9; S. REP. No. 63-698, at 3.

125 See John S. McGee, Predatory Price Cutting: The Standard Oil (N.J.) Case, 1 J.L. $\&$ ECON. 137, 143 (1958).

126 Antidumping Act of Sept. 8, 1916, ch. 463, §§ 801-02, 39 Stat. 798 (1916), 
antidumping legislation beginning with the Antidumping Act of 1921, Congress sought to prohibit foreign producers from selling their goods in the United States at lower prices than those sellers were charging in their home markets. ${ }^{127}$ In the 1916 Act, the prohibition took effect only upon proof that the seller possessed a predatory intent. ${ }^{128}$ Later legislation eliminated that intent requirement. ${ }^{129}$ The legislative history of the early twentieth-century antidumping acts shows that Congress viewed the practice of foreign firms selling in the United States at prices below their home-market prices as unfair. ${ }^{130}$

In the two decades following the end of World War I, Congress revisited domestic and international price discrimination in ways that patently reduced the nation's aggregate welfare. The 1921 Antidumping Act was a harbinger of bad things to come. Congress's failure to include a predatory-intent element in that act resulted in a law whose sole object was protectionist: to protect domestic producers from international competition. ${ }^{131}$ Under third-degree price discrimination, aggrieved final purchasers are presumably those facing higher prices than those offered elsewhere. Several antidumping acts, however, offered Americans the opposite: fairness to domestic producers required that they always paid top dollar. With the enactment of the Robinson-Patman Amendments to the Clayton Act (the "Robinson-Patman Act," or "the Act") in 1936, ${ }^{132}$ Congress again revealed a stunning ignorance of, or disdain for, the economics underlying its legislation.

\section{B. The Robinson-Patman Act: Secondary-Line Effects}

The emergence of chain stores, principally in the grocery and drugstore sectors, propelled Congress to enact the Robinson-Patman Act in

repealed by Pub. L. No. 108-429, tit. 2, § 2006(a), 118 Stat. 2597 (2004)).

127 Antidumping Act of 1921, ch. 14, § 201, 42 Stat. 11 (1921), repealed and substantially reenacted by Trade Agreements Act of 1979, 93 Stat. 162 (1979) (codified at 19 U.S.C. $\$ 1673$ (2006)).

128 Thus, the 1916 Act required proof that the seller sold the articles in question "with the intent of destroying or injuring an industry in the United States, or of preventing the establishment of an industry in the United States, or of restraining or monopolizing any part of trade and commerce in such articles in the United States." Antidumping Act of Sept. 8, 1916, ch. 463, §§ 801-02, 39 Stat. 798 (1916), repealed by Pub. L. No. 108-429, tit. 2, \& 2006(a), 118 Stat. 2597 (2004).

129 See Antidumping Act of 1921 \& 201.

130 See Gifford, supra note 92, at 299-300.

131 See Antidumping Act of $1921 \S 201$.

132 Robinson-Patman Act of June 19, 1936, ch. 592, §§ 1-4, 49 Stat. 1526 (codified at 15 U.S.C. §§ 13(a)-(b), 21a (2006)). 
1936. The proponents of the legislation were members of the United States Wholesale Grocers Association who were losing business to the new chains and small, retail grocery enterprises, druggists, and food brokers who found themselves in competition with the new chains. ${ }^{133}$ The chains were efficiently run, ${ }^{134}$ and because they were able to purchase in bulk, they often were able to obtain their inventories at lower cost than were their more traditional competitors. ${ }^{135}$ The Federal Trade Commission ("FTC"), after studying the operation of the chains, had issued a critical Report on Chain Stores ("Report"). ${ }^{136}$ The Report, combined with the lobbying efforts of the small retailers and their trade associations, persuaded Congress to respond.

When Congress enacted the Robinson-Patman Act, it sought explicitly to eliminate a competitive advantage that it believed the large chain stores unfairly held over the traditional smaller retailers. ${ }^{137}$ Although the term unfair does not appear in the Robinson-Patman Act, it was widely described as directed towards the elimination of this unfair advantage and the imposition of an even playing field between the chains and their smaller competitors. As several courts have stressed, "it is fairness, as Congress perceives it, that Robinson-Patman is all about." 138

During the incubation period of the Robinson-Patman Act, large scale retailers such as $A \& P$ clearly benefited from both greater efficiency and superior bargaining power. ${ }^{139}$ Innovative resource savings in distribution during this period rivaled other economic

133 See, e.g., Frederick M. ROWE, PRice Discrimination Under the RobinsonPatman ACt 11-13 (1962); see also Hugh C. Hansen, Robinson-Patman Law: A Review and Analysis, 51 FORDHAM L. REV. 1113, 1122 (1983).

134 See, e.g., Fed. TRADE COMM'N, FINAL REPORT ON tHe Chain STORE INVESTIGATION, S. Doc. No. 74-4, at 66-71 (1st Sess. 1935) [hereinafter CHAIN STORE REPORTl (using gross margins as measure of efficiency and reporting lower gross margins for both grocery and drug chains).

135 For an example of the discussion of A\&P's purchasing strategy involving differentiated products, see M.A. ADELMAN, A\&P: A STUDY IN PRICE-COST BEHAVIOR AND PUBLIC POLICY 140-46 (1959); see also CHAIN STORE REPORT, supra note 134, at 24.

136 ChAIN STORE REPORT, supra note 134; see Rowe, supra note 133, at 9.

137 See FTC v. Morton Salt Co., 334 U.S. 37, 43 (1948) ("The legislative history of the Robinson-Patman Act makes it abundantly clear that Congress considered it to be an evil that a large buyer could secure a competitive advantage over a small buyer solely because of the large buyer's quantity purchasing ability.").

138 Dagher v. Saudi Refining, Inc., 369 F.3d 1108, 1123 (9th Cir. 2004) (quoting Alan's of Atlanta, Inc. v. Minolta Corp., 903 F.2d 1414, 1422 (11th Cir. 1990)), rev'd, 547 U.S. 1 (2006).

139 See ADELMAN, supra note 135 , at 10-12. 
advances in quantitative importance. ${ }^{140}$ To the extent that the low prices obtained by large scale retailers reflected cost differences, there was no price discrimination in an economic sense. Superior bargaining power was not an illegitimate advantage. John Kenneth Galbraith cites the ability to lower purchase price as an example of "countervailing power" between large buyers and sellers. ${ }^{141}$ Strong and increasing retail competition passed most of the savings through to the final purchaser.

The FTC aggressively enforced the Robinson-Patman Act until the 1970s. ${ }^{142}$ The Supreme Court's decision in FTC v. Morton Salt Co. assisted both the FTC's enforcement efforts and plaintiffs in private lawsuits by erecting a presumption of illegality whenever proven that a defendant supplier sold goods at different prices to competing merchants. ${ }^{143}$ Because the bargaining power of chains purchasing in bulk forced concessions from suppliers, ${ }^{144}$ the Act protected small retailers at the expense of consumers. Indeed, the objective of the Act was to burden consumers with higher chain store prices, just as the antidumping laws have raised import prices faced by consumers.

\section{Primary-Line Effects}

The original version of $\S 2$ of the Clayton $\mathrm{Act}^{145}$ was directed against predatory pricing, but the addition of language in the RobinsonPatman Act expanded the focus of $\$ 2$ to include a concern with protecting the reselling customers of the discriminating seller and their own customer resellers. The Robinson-Patman Act did nothing to detract from the Clayton Act's original concern with protecting the rivals of the discriminating seller from the impact of its low prices. Indeed, in the three decades following the enactment of the RobinsonPatman Act, the FTC and the courts began to direct $\& 2$ against price discrimination whose effects were felt primarily by the seller's rivals, even when the seller was not acting predatorily as Congress envisioned in $1914 .{ }^{146}$

\footnotetext{
140 See Jack Triplett \& Barry Bosworth, Productivity in the U.S. Services SECTORS: NEW SOURCES OF ECONOMIC GROWTH 1-5 (2004).

141 See John K. Galbraith, American Capitalism: The Concept of Countervailing POWER 125 (1952).

142 See discussion supra notes $121-25$ and accompanying text.

143 FTC v. Morton Salt Co., 334 U.S. 37, 54-55 (1948).

144 See, e.g., Rowe, supra note 133 , at 4.

145 See supra notes $121-25$ and accompanying text.

146 Utah Pie Co. v. Cont'l Baking Co., 386 U.S. 685, 702-03 (1967); Samuel H. Moss, Inc., v. FTC, 148 F.2d 378, 379-80 (2d Cir. 1945), cert. denied, 326 U.S. 734
} 
As amended, \& 2 prohibited "primary line" effects: non-predatory price discrimination that adversely affected the rivals of the discriminating seller. This expansion in scope was related to the confusing language that Congress employed in the Robinson-Patman Act, which made price discrimination unlawful where the discrimination might "injure, destroy, or prevent competition with any person who either grants or knowingly receives the benefit of such discrimination, or with customers of either of them." ${ }^{147}$ This language intended to prohibit discrimination that imposed a competitive disadvantage upon the customers of the discriminating seller. ${ }^{148}$ The choice of words was particularly unfortunate, however, because in referring to injuring competition with the customer, the provision appears to equate harm to the customer with harm to competition. In so doing, it attributes a meaning to "competition" that is significantly different from its commonly understood meaning. By an analogous construction of the statutory language, the reference to injuring, destroying or preventing competition with "any person who grants ... such discrimination" would equate harm to rivals of the discriminating seller with harm to competition, thereby making the discrimination unlawful. For a time extending into the late 1960s, this construction appears to have influenced the way the courts approached claims of primary-line injury. ${ }^{149}$

As antitrust observers have long remarked, competition - as generally understood by business persons, economists, and the public at large - involves business firms attempting to take sales away from their competitors by undercutting them or surpassing them on the quality or attractiveness of their products. ${ }^{150}$ Whenever a firm succeeds in taking business away from one of its rivals, it has "harmed" or "injured" that rival. Injuring rivals by diverting business away from them is competitive activity par excellence. Yet the FTC and the courts

(1945); In re Maryland Baking Co., 52 F.T.C. 1679, 1683-84 (1956), modified and affd, 243 F.2d 716 (4th Cir. 1957), order modified, 53 F.T.C. 1106 (1957).

14715 U.S.C. \& 13 (2006).

148 See In re Morton Salt Co., 39 F.T.C. 35, $42-43$ (1944), modified, 40 F.T.C. 388 (1945), order vacated, 162 F.2d 949 (7th Cir. 1947), rev'd, 334 U.S. 37 (1948); H.R. REP. No. 74-2287, at 7 (1936); S. REP. No. 74-1502, at 4-6 (1936); Daniel J. Gifford, Assessing Secondary-Line Injury Under the Robinson-Patman Act: The Concept of “Competitive Advantage," 44 GEO. WASH. L. REv. 48, 48-51 (1975).

149 See, e.g., cases cited supra note 146.

150 See, e.g., Ward S. Bowman, Restraint of Trade by the Supreme Court: The Utah Pie Case, 77 YALE L.J. 70 (1967) (protesting Supreme Court's ruling in Utah Pie as antagonistic to competition understood as striving by firms to capture business from their rivals by under-pricing them). 
soon found exactly that kind of activity unlawful under the RobinsonPatman Act.

Within the first decade after the Robinson-Patman Act was enacted, the FTC ruled that a company had unlawfully discriminated because its lower prices "tended to divert trade to the respondent from its competitors." ${ }^{151}$ On review of the FTC's order, the U.S. Court of Appeals for the Second Circuit upheld the FTC, asserting " $[\mathrm{t}$ ] hat these findings supported the [FTC's] order is too obvious to admit of discussion." 152 In the course of its opinion, the court construed the statutory language to "no doubt mean that the lower price must prevent, or tend to prevent, competitors from taking business away from the merchant which they might have got, had the merchant not lowered his price below what he was charging elsewhere." 153

Under the Second Circuit's approach, proof that a seller offered two prices was sufficient to raise a presumption of unlawfulness. ${ }^{154}$ The defendant seller could overcome that presumption by proving that its low prices did not in fact divert sales away from its competitors, or by otherwise bringing itself within one of the Act's defenses. ${ }^{155}$ Although other circuits did not always deem any diversion of sales to be unlawful, along with the FTC, they tended to find a seller's discriminatorily low prices increasingly problematic as those prices deeply undercut the seller's rivals, which significantly altered market shares. ${ }^{156}$ Thus, the FTC's 1957 ruling against Anheuser-Busch's localized price reduction in St. Louis took this approach. ${ }^{157}$ In that

151 Samuel H. Moss, Inc., 36 F.T.C. 640, 648 (1943), affd, Samuel H. Moss, Inc. v. FTC, 148 F.2d 378, 379 (2d Cir. 1945).

152 Samuel H. Moss, Inc. v. FTC, 148 F.2d 378, 379 (2d Cir. 1945), cert. denied, 326 U.S. 734 (1945).

153 Id. The Commission took a similar approach in In re Anheuser-Busch, Inc., 54 F.T.C. 277, 300 (1957), order set aside, 265 F.2d 677 (7th Cir. 1959), rev'd, 363 U.S. 536 (1960), remanded to 289 F.2d 835 (7th Cir. 1961).

154 See Moss, 148 F.2d at 379. The presumption used by the Commission and the Second Circuit in Moss made possible the proof of a primary-line case (a case in which competitors of the discriminating seller were adversely affected) through proof only of discrimination. In FTC v. Morton Salt Co., 334 U.S. 37, 46-47 (1948), the Supreme Court authored a presumption was directed towards proof of a secondary-line case (a case in which the purchasers or their customers were adversely affected) through proof only of discrimination in a "substantial" amount and proof that the favored and disfavored purchasers were in competition for the resale of the goods involved.

155 Moss, 148 F.2d at 379.

156 See Daniel J. Gifford, Primary-Line Injury Under the Robinson-Patman Act: The Development of Standards and Erosion of Enforcement, 64 MiNN. L. REV. 1, 69 (1979).

157 See In re Anheuser-Busch, 54 F.T.C. at 300. 
case, the FTC equated a substantial diversion of business with competitive harm:

No other circumstance [than the discriminatorily-low price] will account for the fact that, while respondent more than tripled its sales, most of its competition suffered such serious declines. This almost speaks for itself. Respondent's gains could only have been made at the expense of competition since the total sales in the St. Louis market did not increase by any such substantial amount as the sales of respondent and the small combined increase in sales by all of the other competitors could not begin to account for the losses experienced by Falstaff, G.B. and G.W. Respondent's price discriminations manifestly resulted in a substantial diversion of sales from competitors to itself. ${ }^{158}$

This use of the Act to protect competitors became especially perverse when the FTC and the courts condemned local price reductions that reflected scale economies. In several cases, a business firm that reduced local prices in order to increase its sales from a plant with significant scale economies was condemned under the RobinsonPatman Act. ${ }^{159}$ In these cases, courts equated the changes in the local market share that resulted from the seller's high-volume, low-price sales with injury to the seller's rivals and thence with harm to competition. In 1967, the use of the Robinson-Patman Act to protect rivals of a discriminating seller reached its apogee in the now infamous case Utah Pie Co. v. Continental Baking Co. ${ }^{160}$ There, the Supreme Court construed the Act to protect local suppliers against a national rival's attempt to enlarge its local sales by geographically limited price reductions. The Court referred to "radical price cuts" and "drastically declining price structure" as indicative of competitive

158 Id

159 See Standard Oil Co. v. FTC, 340 U.S. 231, 249-50 (1951); Cont'l Baking Co. v. Old Homestead Bread Co., 476 F.2d 97, 104 (10th Cir. 1973), cert. denied, 414 U.S. 975 (1973); United States v. N.Y. Great Atl. \& Pac. Tea Co., 67 F. Supp. 626, 671 (E.D. 1ll. 1946), affd, 173 F.2d 79 (7th Cir. 1949); United Fruit Co., 82 F.T.C. 53, $151-54$ (1973), affd in part, rev'd in part sub nom., Harbor Banana Distrib., Inc. v. FTC, 499 F.2d 395 (5th Cir. 1974); Forster Mfg. Co., 62 F.T.C. 852, 902 (1963), vacated and remanded, 335 F.2d 47 (1st Cir. 1964); C.E. Nieoff \& Co., 51 F.T.C. 1114, 1126 (1955), modified and affd, 241 F.2d 37 (7th Cir. 1957), order reinstated, affd sub nom., Moog Indus., Inc. v. FTC, 355 U.S. 411 (1958); see also Daniel J. Gifford, Promotional Price-Cutting and Section 2(a) of the Robinson-Patman Act, 1976 WIS. L. REV. 1045, 1076-77 \& n.126.

160 Utah Pie Co. v. Cont'l Baking Co., 386 U.S. 685 (1967). 
harm. ${ }^{161}$ In reality, however, the localized price cuts gave rise to a period of intense price competition that eroded the market share of the locally dominant seller and substantially expanded the total volume of product sold by all companies. ${ }^{162}$

\section{Robinson-Patman Retrenchment}

In the last quarter century, the Robinson-Patman Act has come into disfavor. The so-called antitrust revolution that occurred in the 1970s reflected a new understanding by the courts that the antitrust laws focus upon efficiency, and thus the generation of income and wealth, rather than upon fairness or even rivalry for its own sake. ${ }^{163}$ The first hint of this new focus came in 1974. That year, the Supreme Court ruled against the government in a merger case for the first time in over a quarter century, ${ }^{164}$ holding that the government had failed to show by economically viable evidence that the mergers would be likely to affect competition adversely. ${ }^{165}$ Subsequent cases, especially the Court's 1977 decision in Continental T.V., Inc. v. GTE Sylvania, Inc., confirmed this new orientation. ${ }^{166}$ Under the previous approach that equated rivalry with competition, the law could really protect producers, rather than consumers or total welfare, under the guise of maintaining rivalry ${ }^{167}$ Indeed, prior to the revolution of the 1970 s, courts had indicated that there was a place in antitrust law for the protection of small business firms, just because they were small. ${ }^{168}$ From at least 1977 onwards, however, there was no room in antitrust law for the protection of even small competitors from intense

161 Id. at $703 \&$ n.14.

162 See id. at 691-92 n.7 (tables).

163 For a discussion of the phases of U.S competition policy that considers this transition, see Daniel J. Gifford \& Robert T. Kudrle, Alternative National Merger Standards and the Prospects for International Cooperation, in THE POLITICAL ECONOMY OF INTERNATIONAL TRADE LAW: ESSAyS IN HONOR OF ROBERT E. HudEC 208-47 (Daniel L.M. Kennedy \& James D. Southwick eds., 2002).

164 See United States v. Columbia Steel Co., 334 U.S. 495, 507-08 (1948).

165 See United States v. Conn. Nat'l Bank, 418 U.S. 656, 659-60 (1974); United States v. Marine Bancorp., 418 U.S. 602, 622-23 (1974); United States v. Gen. Dynamics Corp., 415 U.S. 486, 510-11 (1974).

166 Cont'l T.V., Inc. v. GTE Sylvania Inc., 433 U.S. 36, 54-55 (1977).

167 See, e.g., Olympia Equip. Leasing Co. v. W. Union Tel. Co., 797 F.2d 370, 375

(7th Cir. 1986) (referring to change in emphasis in antitrust law from promoting rivalry to fostering efficiency).

168 See Brown Shoe Co. v. United States, 370 U.S. 294, 344 (1962); United States v. Aluminum Co. of Am., 148 F.2d 416, 427, 428-29 (2d Cir. 1945). 
competition. This new focus upon efficiency affected the way that $\$ 2$ of the Clayton Act is now construed.

In its Brooke-Group Ltd. v. Brown \& Williamson Tobacco Corp. decision, the Supreme Court reconsidered the structure of section two of the Clayton Act. ${ }^{169}$ The Court concluded that under the RobinsonPatman Act, cases concerned with so-called primary-line harm must meet the same standards for proof of predatory pricing as do cases under the Sherman Act. ${ }^{170}$ Although the Court did not parse section two's language, it effectively held that section two contains two sets of provisions. The first set of provisions dates from 1914 and is directed only against predatory pricing. ${ }^{171}$ This interpretation is likely based upon the apparent intent of Congress at the time of enactment. ${ }^{172}$ The second set of provisions is composed of the language directed against discrimination affecting resellers contained in the Robinson-Patman Act. This language is confined to the Robinson-Patman Act's main objective: deterring discrimination that disadvantages some business firms purchasing from a discriminating seller vis-à-vis their rivals.

Even under this new approach to the interpretation of the RobinsonPatman Act, its anticompetitive potential remains substantial. Primaryline harm is no longer a matter of concern unless discriminatorily low prices are below the measures of cost employed by the courts to identify predatory pricing. ${ }^{173}$ Yet the Act continues to make discrimination that disadvantages business customers vis-à-vis their rivals unlawful. Although the Robinson-Patman Act's objectives are to secure fair competitive conditions, that objective is widely seen as misplaced. Strict enforcement of the Act would likely impose rigidity upon pricing that would discourage price competition and foster oligopolistic pricing behavior, effects that run counter to the procompetitive policies of the other antitrust laws. Indeed, the Supreme Court has always recognized the possibility of conflict between the Robinson-Patman Act and the Sherman Act, and has indicated that in cases of conflict, the procompetitive policies of the Sherman Act should prevail. ${ }^{174}$ The FTC no longer sees enforcement of the

169 Brooke Group Ltd. v. Brown \& Williamson Tobacco Corp., 509 U.S. 209, 21927 (1993) (effectively overruling Utah Pie Co. v. Cont'l Baking Co., 386 U.S. 685 (1967)).

170 Id. at 222.

171 See supra notes $121-25$ and accompanying text.

172 See supra notes 121-25 and accompanying text.

173 Brown \& Williamson, 509 U.S. at 222.

174 See United States v. U.S. Gypsum Co., 438 U.S. 422, 458-59 (1978); see also Automatic Canteen Co. of Am. v. FTC, 346 U.S. 61, 74 (1953) (upholding Sherman Act policies over potentially conflicting Robinson-Patman Act policies). In the recent 
Robinson-Patman Act as a priority. ${ }^{175}$ Recently, the Antitrust Modernization Commission has called for the repeal of the RobinsonPatman Act because it hinders competitive behavior. ${ }^{176}$ Although courts continue to apply it, they construe such cases narrowly. Indeed, a number of lower courts have taken new interpretative approaches that have breathed elements of flexibility into the Act. ${ }^{177}$ As a result, few plaintiffs successfully recover under the Robinson-Patman Act. ${ }^{178}$ Nevertheless, the Act continues to burden the unlucky firms targeted as defendants with substantial litigation costs. ${ }^{179}$

Simco decision finding Volvo not in violation of the Robinson-Patman Act in its differential treatment of dealers, Justice Stevens's dissenting opinion hinted that the myriad technical arguments made by the majority could mask antipathy to the substance of the law: "[Although] I do not suggest that disagreement with the policy of the Act has played a conscious role in my colleagues' unprecedented decision today." Volvo Trucks North America, Inc. v. Reeder-Simco GMC, Inc., 546 U.S. 164, 188 (2006). Justice Stevens's dissent (for himself and Justice Thomas) pointedly noted that " $[t]$ he exceptional quality of this case provides strong reason to enforce the Act's prohibition against discrimination even if Judge Bork's evaluation [that the law was based on 'wholly mistaken economic theory'] (with which I happen to agree) is completely accurate." Id. One inference from all of this is that the entire Supreme Court rejects Robinson-Patman, but members differ in how that rejection should be expressed.

175 See Scott Martin \& Irving Scher, The Robinson-Patman Act: Sellers' and Buyers' Violations and Defenses, 1649 P.L.I./CORP. 553, 561 (2008) (reporting that FTC had brought average of 40 Robinson-Patman cases per year from 1937 to 1971, that after 1980 , FTC instituted only 1-2 cases per year, and that currently there are no Robinson-Patman cases on Commission's docket).

176 AnTItrust MODERnization COMM'N, supra note 11, at 312, 317.

177 See Boise Cascade Corp. v. FTC, 837 F.2d 1127, 1139-40 (D.C. Cir. 1988); Richard Short Oil Co. v. Texaco, Inc., 799 F.2d 415, 420 (8th Cir. 1986).

178 ANTITRUST MOdERNizATION COMm'N, supra note 11, at 316.

179 See Feeser's, Inc. v. Michael Foods, Inc., 498 F.3d 206, 216 (3d Cir. 2007); Frieghtliner of Knoxville, Inc. v. DaimlerChrysler Vans, LLC, 484 F.3d 865, 871-74 (6th Cir. 2007); Lewis v. Philip Morris, Inc., 355 F.3d 515, 534 (6th Cir. 2004); Caribe BMW, Inc. v. Bayerische Moteren Werke Aktiengesellschaft, 19 F.3d 745, 74852 (1st Cir. 1994); DeLong Equip. Co. v. Wash. Mills Abrasive Co., 887 F.2d 1499, 1515-17 (11th Cir. 1989); Krist Oil Co. v. Bernick's Pepsi-Cola of Duluth, Inc., 354 F. Supp. 2d 852, 858 (W.D. Wis. 2005); Allied Sales \& Serv. Co. v. Global Indus. Techs., Inc., 2000-1 Trade Cas. (CCH) II 72,953, No. 97-0017-CB-M, 2000 U.S. Dist. LEXIS 7774, at *31-34 (S.D. Ala. May 1, 2000); Calumet Breweries, Inc. v. G. Heileman Brewing Co., 951 F. Supp. 749, 753-56 (N.D. Ind. 1994). 


\section{PRICE DisCRIMINATION AND THE LAW IN THE EUROPEAN UNION}

\section{A. Price Discrimination and Article 82(c) of the EC Treaty}

The Treaty of Rome ("EC Treaty") created the European Common Market in 1957. ${ }^{180}$ Two articles within the EC Treaty are the foundation of European competition law: Articles 81 and 82. These Articles contain provisions that target price discrimination. Article $81(1)(d)$ specifically bars agreements that "apply dissimilar conditions to equivalent transactions with other trading parties, thereby placing them at a competitive disadvantage." 181 Article 82 uses virtually identical language to prohibit dominant firms from "applying dissimilar conditions to equivalent transactions with other trading parties, thereby placing them at a competitive disadvantage." 182 On their face, these provisions appear to prohibit price discrimination by a supplier between two competing purchasers, as a higher price to one dealer might well be deemed to competitively disadvantage it vis-à-vis the other. The focus of these provisions is thus upon protecting purchasers from what is called "secondary-line" harm when similar situations are considered under the Robinson-Patman Act.

It is not at all surprising that the EC Treaty would incorporate policies similar to those of the Robinson-Patman Act, as the drafters of the antitrust provisions of the Treaty drew heavily upon the models provided by American antitrust law. ${ }^{183}$ Indeed, in the first decade or so of its operation, the decisions of the European Commission and of the Court of Justice embodied policies that resembled those underlying the U.S. decisions of that period. ${ }^{184}$ After the so-called U.S. antitrust

180 Treaty of Rome Establishing the European Economic Community, Mar. 25, 1957, 298 U.N.T.S. 11. Several treaties have amended the initial treaty. Unless otherwise specified, all citations will accordingly be made to the current Consolidated Version of the Treaty Establishing the European Community ("EC Treaty").

181 EC Treaty art. 81(1)(d) (Dec. 24, 2002).

182 Id. art. 82(c).

183 See, e.g., Guy Pevtchin, The E.C. - An Example of Breaking Down the Barriers of Sovereignty-Implications for Canada and the United States, 24 CAN.-U.S. L.J. 89, 89 (1998) ("[T]he draftsmen of the Treaty of Rome went to the best source of knowledge on antitrust to write the well-known Articles 85 and 86 of that treaty, the equivalent of the Sherman Act. Articles 85 and 86 were drafted by an American lawyer named Robert Bowie from Harvard University."). But see David Gerber, Constitutionalizing the Economy: German Neo-Liberalism, Competition Law and the "New Europe," 42 AM. J. COMP. L. 25, 54 (1994).

184 Thus, for example, in a contemporary discussion of antitrust policy, Carl Kaysen and Donald Turner, although criticizing the rigidities of the Robinson-Patman Act, nonetheless contemplated that a prohibition of price discrimination should be a 
revolution in the 1970s, however, the two legal systems grew less alike, although there are some signs that the gap is now narrowing. ${ }^{185}$

During drafting of the EC Treaty in the late 1950s, the RobinsonPatman Act was widely seen as a major component of U.S. antitrust law. ${ }^{186}$ During this period of enforcement, action by the FTC was large and growing. The FTC and courts repeatedly construed the Act to prohibit price discrimination that would confer "competitive advantages" on favored buyers. ${ }^{187}$ The widespread public acceptance of the policy goals of the Robinson-Patman Act during this period may have been felt in Europe by the drafters of the competition law provisions of the new European Common Market. ${ }^{188}$ An analogous concern that competitive disadvantages not be imposed upon customers vis-à-vis their rivals is written into the text of Articles $81(1)(d)$ and $82(c)$.

In Europe, however, the provisions of Article 81(1)(d) have a more limited application than the analogous provisions of the RobinsonPatman Act. Although the Robinson-Patman Act extends to all sales, the coverage of Article 81 is limited to agreements or other concerted action. Given that European antitrust authorities consider ordinary sales transactions unilateral actions, they do not fall within the scope of Article 81. ${ }^{189}$

Because of this somewhat narrow understanding of agreement, it appears that the only sales transactions that fall within Article 81(1)(d) are those covered by agreements between independent companies that mandate discriminatory pricing practices, a construction that effectively removes price discrimination from the purview of Article $81(1)(d)$. Thus, the concerns of the European authorities over price discrimination are concentrated largely on price discrimination by dominant firms under Article 82 . The emphasis on

part of the antitrust laws. Indeed, these authors provided a model for legislation prohibiting price discrimination that they believed was superior to the RobinsonPatman Act. See KAYSEN \& TURNER, supra note 86, at 184-85.

185 For an evaluation, see Gifford \& Kudrle, supra note 109, at 424.

186 See supra note 182 and accompanying text.

187 Gifford, supra note 148 , at 48 .

188 See supra note 181 and accompanying text.

189 See Case C-73/95, Viho Europe BV v. Comm'n, E.C.R. I-5457, 161 (1996). In that decision Viho complained that a supplier (Parker) offered it discriminatorily unfavorable supply prices. The Court rejected that contention on the ground that the discrimination at which Article $81(1)$ (d) is directed cannot be "the result of unilateral conduct by a single undertaking." Id; see also S.O. Spinks, Exclusive Dealing, Discrimination, and Discounts Under EC Competition Law, 67 ANTITRUST L.J. 641, 66869 (2000); Michel Waelbroeck, Price Discrimination and Rebate Policies Under EU Competition Law, 1995 FORDHAM CORP. L. INST. 147, 149 (1996) 
price discrimination by dominant firms appears to be an advance over the American approach, which has taken no account of the size or prominence of the discriminating seller. Yet the European authorities take a broad approach to dominance: a firm need not be a monopoly in order to be deemed "dominant." Accordingly, price discrimination in the European Community by large and successful firms among competing customers is potentially vulnerable to attack under Article 82.

Europe offers a rich caselaw on price discrimination as one form of abuse of a dominant position. In United Brands Co. v. Commission of the European Communities, ${ }^{190}$ a foundational Article 82 case, the Court of Justice ruled that United Brands contravened Article 82(c) by selling bananas to several national distributors at different prices. Because those distributors each resold their banana inventories in different local markets, ${ }^{191}$ they were in fact not in competition with each other, and thus none of them could be disadvantaged in competition with any of the others. It is unclear whether the Court failed to understand the competitive relationships among the distributors or whether it was ruling that a showing of competitive disadvantage was not required under Article 82(c) despite its language. The Court, however, appears to have mistakenly equated United Brand's pricing practices with dividing the banana market along national lines, a practice that, in the Court's view, strikes at the heart of the single-market objective of the EC Treaty. ${ }^{192}$

In another foundational case, Hoffmann-La Roche \& Co. $v$. Commission of the European Communities ("Hoffman-La Roche"), ${ }^{193}$ the Court condemned so-called "fidelity rebates" as violations of Article 82(c). ${ }^{194}$ These consisted of rebates conditioned upon the purchasers buying all or a large percentage of their requirements from the seller. In that case, the Court was primarily concerned with the effects of fidelity rebates impeding the seller's rivals from selling to the latter's customers. The Court thus appeared use Article 82(c) as a means for protecting the seller's rivals, even though the Article is concerned with protecting the seller's customers. In analyzing the case under the

190 Case 27/76, United Brands Co. v. Comm'n, E.C.R. 207, q 300 (1978).

191 See Damien Geradin \& Nicolas Petit, Price Discrimination Under EC Competition Law: Another Antitrust Doctrine in Search of Limiting Principles?, 2 J. COMPETITION L. \& ECON. 479, 522-23 (2006).

192 See Joined Cases 56/64 \& 58/64, Consten \& Grundig v. Comm'n, 1966 E.C.R. 299, ql 341 .

193 Case 85/76, Hoffmann La Roche \& Co. v. Comm'n, E.C.R. 461, q 90 (1979).

194 Id. 
Robinson-Patman Act, the Court focused on primary-line effects effects on the rivals of the discriminating seller. The Court nonetheless employed a legal provision directed at secondary-line effects - effects on the seller's customers - to support its condemnation of HoffmannLa Roche's discrimination. ${ }^{195}$

A significant part of EU caselaw is concerned with protecting competitors of a dominant firm. The European courts are especially concerned with a dominant firm's discount practices that impede rivals from selling to the dominant firm's customers. These practices are considered exclusionary. They include "fidelity" or "loyalty" rebate systems, such as those involved in Hoffman-La Roche (in which rebates are keyed to a customer purchasing a specified percentage of its requirements from a seller) as well as so-called "target" or "objective" rebate systems in which rebates are keyed to the customer's satisfaction of sales objectives set in absolute amounts. By contrast, so called quantity discounts - in which the price to all buyers is reduced on a uniform schedule as the quantity purchased increases - have generally been upheld as lawful, even when granted by a dominant firm. In its recent decision in British Airways Plc. v. Commission of the European Communities ("British Airways"), however, the Court of First Instance observed that the implicit justification for quantity discounts is that they reflect the lower unit costs often incurred by sellers in large-volume transactions. ${ }^{196}$ Accordingly, the Court hinted that when a dominant firm's criteria for granting such a rebate reveal that it is not cost-related, the rebate may be viewed more like a fidelity or target rebate impeding rivals from selling to the dominant firm's customers. ${ }^{197}$ Moreover, discount systems in which the discounts are computed on sales over a long reference period have been deemed to have similar exclusionary effects because the value of the discount significantly increases over the length of the period, and thus exerts growing pressure on the buyer to remain with its current supplier. ${ }^{198}$ Although the Court of Justice has condemned fidelity and target rebates under Article 82(c), it has also condemned fidelity and target rebate systems as abuses under Article 82's general language, without

195 See Geradin \& Petit, supra note 191, at 525.

196 Case T-219/99, British Airways Plc. v. Comm'n, E.C.R. II-5917, III 246-47 (2003).

197 Id.

198 See Case 322/81, NV Michelin v. Comm'n, E.R.C. 3461, II 81-82 (1983); see also Commission Decision 92/163/EEC, Tetra Pak II, 1992 O.J. (L 72/1) 174 (1991) (barring aggregation on quantity discounts). 
invoking clause (c). ${ }^{199}$ Indeed, in British Airways, the Court of First Instance asserted that a dominant supplier's fidelity rebate system requiring customers to obtain their supplies exclusively or almost exclusively from that supplier is abusive and therefore in violation of the basic prohibition of Article 82. ${ }^{200}$ Nonetheless, that Court also ruled that the rebate system before it was in fact discriminatory and imposed competitive disadvantages upon customers within the meaning of Article 82(c). ${ }^{201}$

Commentators have criticized the European authorities for misusing Article 82(c) as a means for protecting the rivals of dominant firms. ${ }^{202}$ These individuals contend that Article 82(c) should not apply absent a showing that buyers have been placed at a competitive disadvantage. In those cases, the Court appears to be concerned with primary-line effects, patently not a matter dealt with by Article 82 (c) ${ }^{203}$ When Article 82(c) is invoked, it appears to have been diverted from its ostensible objective of protecting customers of dominant firms into the very different task of protecting rivals of dominant firms.

\section{B. Comparing Article 82(c) with the Robinson Patman Act}

As observed above, ${ }^{204}$ Congress adopted the Robinson-Patman Act in response to the complaints of small business firms of unfair exposure to the competition of large chains stores able to obtain their supplies at lower prices than were their smaller rivals. The Robinson-Patman Act was Congress's attempt to neutralize the bargaining power of the chains vis-à-vis their suppliers, who were frequently small or mediumsize companies. ${ }^{205}$ Although the Robinson-Patman Act directs most of its provisions against the discriminating sellers, its premise is that buying power is misused at the purchaser level. By contrast, Article 82(c) applies only to large sellers that can meet the criteria for "dominance" as used in the EC Treaty. Thus, while Congress

199 See NV Michelin, E.R.C. 3461 TII 86, 91.

200 British Airways, E.C.R. II-5917 III 244-45, 248.

201 Id. 11299.

202 See Damien Geradin \& Nicolas Petit, Price Discrimination Under EC Competition Law: The Need for a Case-by-Case Approach 9 (Global Competition Law Centre, Working Paper No. 07/05, 2007), available at http://www.coleurope.eu/content gclc/documents/GCLC\%20WP\%2007-05.pdf.

203 Case 85/76, Hoffmann La Roche \& Co. v. Comm'n, E.C.R. 461, q1 90 (1979); Case 27/76, United Brands Co. v. Comm'n, E.C.R. 207, II 300 (1978); see also Case T83/91, Tetra Pak International SA v. Comm'n, E.C.R. II-755, II 173 (1994).

204 See supra note 133 and accompanying text.

205 See supra notes $133-41$ and accompanying text. 
ostensibly designed Article 82(c) and the Robinson-Patman Act to prevent buyers from being competitively disadvantaged, the two provisions actually direct their focus in opposite directions. Article 82(c) focuses on the pricing behavior of powerful sellers while the core concern of the Robinson-Patman Act is upon the purchasing behavior of powerful buyers. ${ }^{206}$ During the middle of the twentieth century, the Robinson-Patman Act was also employed to protect the rivals of a discriminating seller, just as Article $82(\mathrm{c})$ is used today. ${ }^{207}$ Under the current interpretation of that Act, however, the seller's rivals have protection only against predatory pricing. ${ }^{208}$

Overall, the dominant thrusts of United States and European legal concerns come close to being mirror images. U.S law represents an historic desire to protect small retail merchants from the competition of powerful buyers. European law, on the other hand, appears focused on protecting initial sellers from the competition of their powerful rivals.

\section{Price Discrimination Beyond the Article 82(c) Context}

Article $82(\mathrm{c})$ is not the only provision in Article 82 that targets price discrimination. Clause (c) is one of four clauses that describe particular types of behavior that fall within that article's general prohibition against abuses of dominant position. The structure of Article 82, however, makes clear that abuse can take forms other than those referred to in the four clauses. As indicated above, the European Commission and the European courts are increasingly targeting price discrimination as an abuse under Article 82's general clause. In doing so, these authorities frequently describe this abuse as involving "selective" price cuts, a phrase that is literally coextensive with all price discrimination. ${ }^{209}$

206 See supra note 137 and accompanying text.

207 See supra notes 145-79 and accompanying text.

208 See Brooke Group Ltd. v. Brown \& Williamson Tobacco Corp., 509 U.S. 209, 209 (1993); supra notes 169-73 and accompanying text.

209 Case C-62/86, AKZO Chemie BV v. Comm'n, 1991 E.C.R. I-03359, 5 C.M.L.R. 215 (1993), Il 115; Case T-30/89, Hilti AG v. Comm'n, 1991 E.C.R. II-01439, 4 C.M.L.R. 16, 1100 (1992); Case T-228/97, Irish Sugar PLC v. Comm'n, 1999 E.C.R. Il-02969, 5 C.M.L.R. 1300 (1999), III 124, 259, 261 (recognizing dominant firm's selective price cutting as abusive but finding failure of proof). In Case C-395/96 P, Compagnie Mar. Belge Transps. SA v. Comm'n, 2000 E.C.R. I-1365, 4 C.M.L.R. 1076 (2000), the losing defendant argued lawfulness of selective price cutting. See id. II 114. The Court decided otherwise. See id. II 117-21. 
In general, European authorities see selective price cutting as subject to the prohibition against "abuses" of dominant position because they view it as a tool for deterring entry by rivals or for forcing them to exit the market, and thus as a device for obtaining or preserving a dominant position. ${ }^{210}$ As discussed below, European authorities appear to rank selective price cutting as at least as much of a threat to a competitive market structure as below-cost predatory pricing. Indeed, they approach selective price cutting as on a par with selling below average variable cost, behavior which the Court of Justice views as unambiguously abusive. This is an approach that differs radically from U.S. antitrust law, which protects competitors only from predatory pricing and not normally from above-cost price competition.

In the EU caselaw, both predatory pricing and selective price cutting are seen as fostering dominance and thus as a threat to competitive market conditions. In AKZO Chemie BV v. Commission, an early and leading case, the abuse consisted of both predatory pricing and selective price cuts. ${ }^{211}$ Because the selective price cuts were at belowcost levels, the independent significance of selective price cutting was unclear. In the later Hilti $A G v$. Commission case, ${ }^{212}$ however, the European Commission explicitly declared that selective price reductions need not be at below-cost levels in order to constitute abuse. ${ }^{213}$ The European Commission held that a producer of nail guns $^{214}$ abused its dominant position by offering its devices at reduced prices to the customers of new entrants, thereby discouraging entry. ${ }^{215}$ This ruling was upheld on appeal. ${ }^{216}$ Compagnie Maritime Belge Transportations v. Commission held that a shipping conference abused its dominant position when it employed so-called "fighting ships" to offer carriage at reduced rates in competition with rivals, although the reduced rates were not shown to have been below cost. ${ }^{217}$

The results in these cases reflect the way the European Commission and the European courts analyze the dominant firm's intention. Intent

\footnotetext{
210 See, e.g., Compagnie, 2000 E.C.R. I-1365 II 132.

211 AKZO, 1991 E.C.R. I-03359.

212 Hilti, 1991 E.C.R. II-01439.

213 Commission Decision 88/138, art. 86, 1987 O.J. (L 65) 19 (EEC).

214 These devices are known as PAF nail guns, PAF standing for "power actuated fastening."

215 Hilti, 1991 E.C.R. II-01439 at Il 83.

216 Id. II 100.

217 Case C-395/96 P, Compagnie Mar. Belge Transps. SA v. Comm'n, 2000 E.C.R. I1365, 4 C.M.L.R. 1076 (2000).
} 
plays a role in the predatory pricing cases, and these cases are instructive about how the EU authorities approach selective price cutting. The Court of Justice has identified two possible types of predatory pricing. The first type occurs when a dominant seller offers its goods at prices below average variable cost. ${ }^{218}$ The Court of Justice views such behavior as unambiguously predatory and hence abusive. The second type of possibly predatory pricing occurs when a dominant seller offers its goods at prices that are below average total cost but above average variable cost. Courts do not treat this behavior as presumptively predatory because there are legitimate economic rationales for such behavior. Such sales, for example, can minimize losses in a situation of falling demand. In the case of above-average variable-cost pricing, there must be proof that the sales were part of a plan to eliminate a competitor before they will be deemed an abuse. ${ }^{219}$ Thus, according to the Court of Justice, the second category of pricing is ambiguous and there must be evidence of the seller's intent before the pricing can be condemned as abusive. The Court's insistence upon evidence of intent as a means of resolving the ambiguous nature of the firm's behavior in the predatory context is repeated in the context of discriminatory pricing challenged under the general clause of Article 82.

In cases in which the Court of Justice has condemned selective price cutting, the firm in question has directed its price cutting towards customers of one or more rivals. ${ }^{220}$ In the view of the Court of Justice and other EU authorities, this targeting reveals the dominant seller's intention to injure the particular rivals that are threatening its dominance. ${ }^{221}$ With the actor's intent seemingly clarified, its actions are treated as abuses, forbidden by Article 82. Thus, in Akzo, the Court of Justice construed the company's selectively low prices to the customers of its rival ECS as evidence of its intention "to adopt a strategy that could damage ECS" and thus constitute abuse. ${ }^{222}$

European competition law focuses on selective price cutting and predatory pricing for the same reason. Both practices threaten the maintenance of a competitive market structure. Yet the danger in prohibiting various forms of low pricing is that unless the prohibitions narrowly embrace only unambiguously anticompetitive behavior, the

\footnotetext{
218 Case C-62/86, AKZO Chemie BV v. Comm'n, 1991 E.C.R. I-03359, 5 C.M.L.R. 215 (1993), II 71.

219 Id. $91 \mathrm{I} 72$.

220 See, e.g., id. 9 II 114-15; Compagnie, 2000 E.C.R. I-1365 at III 117-21.

221 See cases cited supra note 220

222 AKZO, 1991 E.C.R. I-03359 II 115; see also Compagnie, 2000 E.C.R. I-1365 q1 128.
} 
prohibitions themselves can create price umbrellas under which inefficient sellers receive protection from legitimate price competition. This result conflicts with the core purpose of competition law. The EU prohibition against selling at below-average-variable-cost prices is finely tuned to target anticompetitive behavior. The Court of Justice correctly states that such pricing has no legitimate economic rationale. ${ }^{223}$ When the $\mathrm{EU}$ authorities target selective price cutting, however, they cannot claim to be limiting their sanctions to behavior that is unambiguously anticompetitive. Indeed, when a firm lowers its price to respond to a rival's incursions on its market, that behavior constitutes the very price competitive behavior that competition laws are designed to foster. The EU authorities are thus operating on a false dichotomy. In the arena of market competition, it is impossible to draw a distinction between intent to take sales away from a rival and intent to injure the rival by doing so. ${ }^{224}$ Evidence that a dominant firm intended to injure a rival by diverting sales away from it, therefore, is nothing more than evidence of intent to compete. The underlying flaw in the EU analysis lies in the premise that price competition is legitimate when conducted with market-wide uniform pricing, but that price reductions targeted to the areas of intense rivalry are suspect.

Many American antitrust observers would view these attempts by EU authorities to distinguish between competition on the basis of market-wide pricing, and competition employing selective price reductions. This is an unfortunate repetition of U.S. experience under the Robinson-Patman Act during the middle of the twentieth century, before the Supreme Court reinterpreted the Act as no longer protecting firms from the price competition of rivals.

When courts construe Article 82(c) of the EC Treaty to prohibit selective price-cutting - just as when construing the RobinsonPatman Act to target nonpredatory primary-line injury ${ }^{225}$ - they do so in pursuit of a policy of fairness to rivals of the favored seller. That fairness, however, comes at the expense of society. In so far as selective price-cutting operates as a mechanism for breaking down supra-competitive pricing, the social cost of fairness is a reinforcement of anticompetitive pricing and a reduction of social welfare, as measured by both the consumer surplus and total surplus standards. As in many other realms, the political feasibility of cleaving ever closer to one of the latter two standards in judging price discrimination is

${ }^{223}$ Case C-333/94 P, Tetra Pak Int'l SA v. Comm'n, 1996 E.C.R. I-5951, 4 C.M.L.R. 662 (1997), I 74; AKZO, 1991 E.C.R. I-03359 9II 70-71.

224 See discussion supra notes 150-62.

225 See supra text accompanying notes 145-79. 
easier in the U.S. than in Europe. In Europe, competition-law authorities appear more concerned with the welfare of all incumbent economic actors than with the competitive process itself.

\section{The Current Policy Frontier in the European Union and the United States: Loyalty Rebates}

A widely used form of discounting rewards sales above a certain level with a lower price on a firm's entire purchases of a product over a specified period (often a year). These discounts are frequently referred to by several names, including: "target" rebates (because the rebates are earned after the buyer's accumulated purchases reach a specified target amount), or "fidelity" or "loyalty" rebates (because they have the effect of maintaining the buyer's loyalty to the seller as a source of supply). The term "loyalty rebates" in the discussion below refers to this class of rebates. Although loyalty rebates have been the subject of antitrust concern in Europe for some time, only a few U.S. cases have considered their lawfulness. ${ }^{226}$ While the European authorities generally view loyalty rebates granted by dominant firms as unlawful, U.S. courts have generally been reluctant to condemn them. European and U.S. courts, as well as antitrust authorities, tend to focus on different aspects of these rebates. For reasons discussed below, this Article suggests that the European courts have misunderstood the likely effects of loyalty rebates and have consequently found antitrust violations where there were none. Conversely, this Article argues that the U.S. courts and antitrust authorities are in the process of developing a properly nuanced evaluation of these practices.

Because the seller offering loyalty rebates extends them to some purchasers but not to others, the rebates involve price discrimination. As with simple price discrimination, loyalty rebates may generate effects on the primary or secondary lines. The EC Treaty focuses on secondary-line effects, but the Court of Justice has directed much of its attention to their effects on the primary line: it tends to see loyalty

226 See Cascade Health Solutions v. PeaceHealth, 515 F.3d 883, 894-911 (9th Cir. 2008); LePage's, Inc. v. 3M, 324 F.3d 141, 154-57 (3d Cir. 2003) (en banc); Concord Boat Corp. v. Brunswick Corp., 207 F.3d 1039, 1058-63 (8th Cir. 2000); SmithKline Corp. v. Eli Lilly, 575 F.2d 1056, 1061-62, 1065 (3d Cir. 1978); Invacare Corp. v. Respironics, Inc., No. 1:04 CV 1580, 2006 WL 3022968, at *10-12 (N.D. Ohio 2006); Masimo Corp. v. Tyco Health Care Group, L.P., No. CV 02-4770 MRP, 2006 WL 1236666, at ${ }^{*} 9,{ }^{*} 12$ (C.D. Cal. 2006); Virgin Atl. Airways Ltd. v. British Airways PLC, 69 F. Supp. 2d 571, 580-81 \& nn.7-8 (S.D.N.Y. 1999); Ortho Diagnostic Sys., Inc. v. Abbott Labs., Inc., 920 F. Supp. 455, 466-71 (S.D.N.Y. 1996); see also J.B.D.L. Corp. v. Wyeth-Ayerst Labs., Inc., 485 F.3d 880, 884-86 (6th Cir. 2007). 
rebates as an anticompetitive weapon directed against competitors of the seller offering those rebates. The U.S. cases that have dealt with loyalty rebates view them as raising issues under the monopolization or attempted monopolization clauses of $\$ 2$ of the Sherman Act. ${ }^{227}$ In analyzing these different approaches, it is helpful to look more closely at loyalty rebates themselves, which fall into two broad classes: singleproduct rebates and multiproduct (or bundled) rebates.

\section{Single-Product Loyalty Rebates}

Buyers accorded single-product loyalty rebates are increasingly tied to the seller as their total purchases approach the target amount. For example, consider the case of a seller, firm $X$, who offers widgets at a price of $\$ 10$, but offers a $\$ 1$ per unit rebate to buyers who buy 100,000 widgets over the course of a year. For buyers who expect to purchase 100,000 widgets during the year, this may be an attractive offer. They have an incentive to confine their purchases to that one seller. When such a buyer purchases the first widget, it likely considers competing offers from rival suppliers, who may be offering competing discounts. When the buyer purchases its second widget, it will incur a slight cost should it decide to switch suppliers, say to firm Y. Assuming that firm $Y$ was offering an identical target rebate, the buyer then would forfeit the \$1 rebate on its first purchase that it would have received from firm $\mathrm{X}$ had it continued to deal with firm $\mathrm{X}$ until its purchases reached the target amount. If the buyer switches after purchasing its second widget from firm $X$, it would forfeit $\$ 2$. Thus the cost of switching suppliers increases as the buyer's purchases from firm $X$ increase. The cost of switching increases gradually at first but grows rapidly later on. After the buyer has purchased 90,000 widgets, the cost of switching would be $\$ 90,000$.

A number of European critics argue that loyalty rebates are anticompetitive because they make it increasingly difficult for rivals, including possible new entrants into the industry, to sell to the customers of a firm - like firm X - that is offering those rebates. Indeed, these critics also contend that a firm offering fidelity rebates will necessarily be selling its product below cost. That position draws upon the analysis described above: as a buyer's purchases increase, the seller is effectively offering that buyer a greater incentive to continue purchasing from that seller. As the buyer's purchases increase, he pays less and less for incremental units. The price for incremental units is

227 See Concord Boat Corp., 207 F.3d at 1045-46; SmithKline Corp., 575 F.2d at 1062; Ortho Diagnonstic Sys., 920 F. Supp. at 468. 
effectively the discount price (\$9) per unit less the rebate on past purchases. As the buyer's purchases increase, the rebate on past purchases increases in amount, eventually growing to the point where the per-unit price of incremental units is negative. This can be represented symbolically as follows:

Let:

$$
\begin{aligned}
& \mathrm{p}=\text { list price } \\
& \mathrm{d}=\text { discount } \\
& \mathrm{T}=\text { target } \\
& \mathrm{q}=\text { amount already purchased }
\end{aligned}
$$

The average per-unit effective price for the block of additional purchases required to meet the target is then:

$$
\frac{(p-d)(T-q)-q d}{T-q}=p-d-[q d]
$$

The effective price decline is rapid as the quantity purchased approaches the target. In the hypothetical discussed above, where the list price is $\$ 10$, the rebate is $\$ 1$, and the target is 100,000 units, the rapid decline in the effective unit price is apparent in the graph below: 


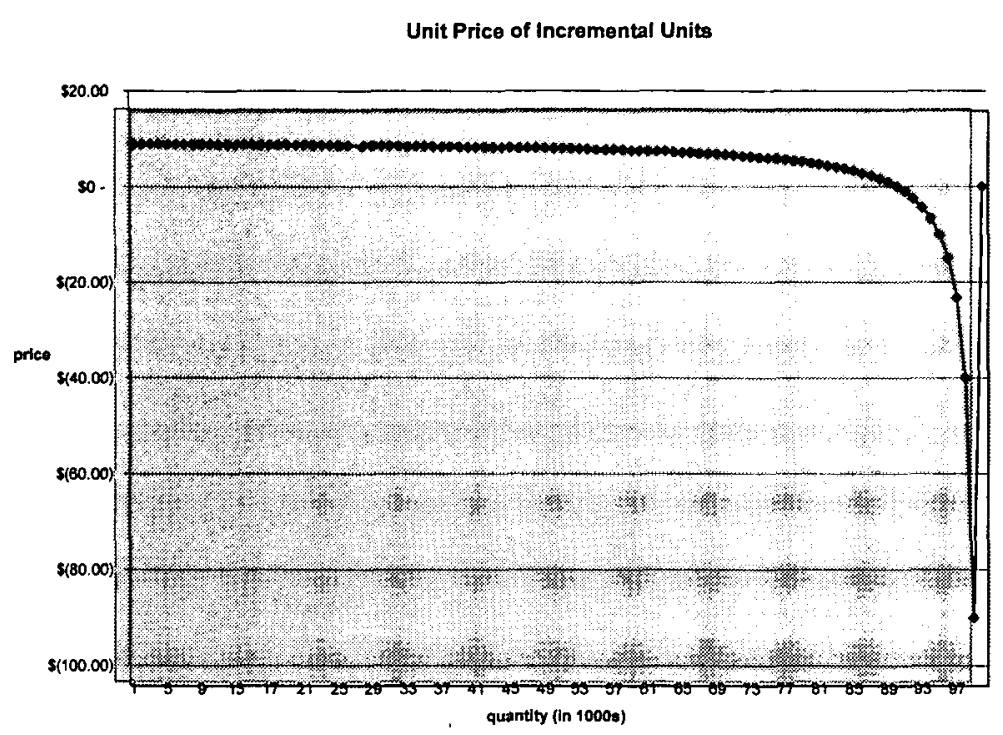

Under this view, the effective unit price, factoring in the rebate, starts at $\$ 9$ and then gradually declines as the rebates accumulate. When the buyer has purchased 90,000 units, the effective unit price for the additional 10,000 units that will take the buyer to the target is zero. At 95,000 units, the effective unit price for the remaining 5,000 units necessary to reach the target is a minus ten dollars $(-\$ 10)$. The unit price continues to fall rapidly. This rapid fall in the unit price of additional purchases is referred to as a "suction effect," apparently referring to the increasing incentive of the buyer to continue purchasing from the same supplier. ${ }^{228}$ At 100,000 units, the price for additional units climbs abruptly to $\$ 9$ and holds steady thereafter.

The potential significance of the mechanism generating the suction effect becomes clear when viewed from the standpoint of an alternative seller, perhaps an entrant. Assume that the purchaser has the characteristics previously described and that this purchaser is buying above the target amount at 105,000 units. Assume further that the entrant faces sharply declining cost with a minimum efficient scale of 10,000 , at which point its costs match those of the incumbent. The entrant, however, has little chance of selling the 10,000 units to the purchaser. If the purchaser has already bought 95,000 units from the incumbent, it would lose $\$ 95,000$ by purchasing the next 5,000 units

${ }^{228}$ Frank P. Maier-Rigaud, Article 82 Rebates: Four Common Fallacies, 2 EUR. COMPETITION J. 85, 87-88 (2006). 
from the entrant. After attaining the target amount of purchases $(\$ 100,000)$, the purchaser would be free to buy additional units from others (including the entrant) at prices of $\$ 9.00$ or below without losing money. If the purchaser in question is the only market for the entrant's goods, and if the purchaser's needs do not reach 110,000 units, the entrant would be incapable of attaining minimum efficient scale.

A number of scholars have analyzed the effect of loyalty rebates in tying the purchaser increasingly to the supplier offering them. ${ }^{229}$ Frank P. Maier-Rigaud of the European Commission's General Competition Directorate, for example, demonstrates the high switching costs that would be incurred by a purchaser as it approached the target amount. ${ }^{230}$ Indeed, Maier-Rigaud challenges other writers' contention that the suction effect was overstated. Maier-Rigaud focuses on the argument that when the demand of a particular customer is greater than the target amount, there are no suction effects on its purchases that exceed the latter. He is particularly concerned with the contention of G. Frederico, who argues that the price a competitor would have to offer to persuade the customer to switch prior to the point at which the customer's purchases reached the target amount would increase as demand increases, because the competitor could offer a price that averages the post-target price with the low pre-target prices. ${ }^{231}$ MaierRigaud dismisses these contentions, claiming that it would be irrational for a seller offering a target rebate to set the target in excess of the expected demand of the customer or substantially below it. ${ }^{232}$

The flaw in the suction effect analysis is that it directs attention away from the focus of competition. The suction effect analysis is not wrong, it is just simplistic. Of course, a customer becomes more committed to a supplier as its purchases approach the target amount that triggers a rebate. Similarly, it becomes increasingly difficult for a rival supplier to divert away that customer's trade until its purchases reach the target amount. The competitive issues involved may be

229 See id. at 88-89; Patrick Greenlee et al., An Antitrust Analysis of Bundled Loyalty Discounts 5 (Econ. Analysis Group Discussion Paper No. 04-13, 2005), available at http://ssrn.com/abstract=600799; Patrick Greenlee \& David S. Reitman, Competing with Loyalty Discounts 7-8 (Econ. Analysis Group Discussion Paper No. 04-2, 2005), available at http://ssm.com/abstract=502303.

230 Maier-Rigaud offers a diagram similar to the one above to demonstrate the "suction effect" encountered by any purchaser approaching the target. Maier-Rigaud, supra note 228 , at 87 .

231 Id. at 89-90; see also Giulio Federico, When Are Rebates Exclusionary?, 26 EUR. COMPETITION L. REv. 477, 477-79 (2005).

232 Maier-Rigaud, supra note 228 , at $91-92$. 
illustrated best by considering the differences between a loyalty rebate and an exclusive supply contract.

During the term of an exclusive supply contract, the customer is committed to its supplier, and rival suppliers find it difficult to divert away those customers. The differences between a target or fidelity rebate and an exclusive supply contract lie in their different incentive structures. With the rebate scheme, the incentive for a customer to remain "loyal" to the supplier increases as the customer's purchases approach the target amount. In the typical exclusive supply contract, the customer is bound by contract to remain loyal to the supplier. The customer can break the contract, but will have to pay damages if it does. The normal damages would be the seller's lost profits. Since the seller would have already earned its profits on its sales up to the time of the breach, the profits are those that the seller would lose from future sales that have been diverted to a rival.

Taking the figures from the example above to examine a supply contract, assume that firm X offers a price of $\$ 9$ per unit to customer A, who commits to purchase its entire year's requirements (of say 100,000 units) from firm X. Further assume that firm X can produce widgets at a cost of $\$ 7$ per unit, so firm $X$ earns a profit of $\$ 2$ per unit. If customer A decides during the term of the contract to purchase from a different supplier, it will be liable in damages for the profits lost to $X$ as a result of A's breach of contract. Thus a rival will have to offer a price to customer A that not only meets firm X's price but that also compensates customer A for the $\$ 2$ profit per unit that constitutes A's liability to $\mathrm{X}$ for the sales lost to $\mathrm{X}$. Thus, the rival would have to offer a price of $\$ 7(\$ 9-\$ 2=\$ 7)$ per unit for new purchases. A competitor could induce the customer to switch at any time by offering a price of just under $\$ 7$ per unit for all new purchases. In order for this to be an attractive option to the rival, however, the rival's costs would have to be less than $\$ 7$ per unit.

If firm $X$ had instead employed the loyalty rebate technique by offering widgets in amounts of less than 100,000 units but at a retroactive price of $\$ 9$ for firms purchasing 100,000 units, a rival offering widgets at $\$ 7$ for new purchases would undercut firm $X$ up to the time that the customer had purchased approximately 67,000 widgets. ${ }^{233}$ Thereafter, switching costs would exert an increasing incentive for the customer to remain with firm $X$. So up to approximately 67,000 units, an equally efficient rival (i.e., with costs

233 More precisely the number is $66,666.7$ units. $x=$ number of units purchased from incumbent and therefore the dollar amount of the potential rebate. (100,000 x) $2=$ the $\$ 2$ per unit savings on purchases from the entrant times the remaining sales. 
not exceeding \$7 per unit) could induce a switch under either an exclusive supply contract or a loyalty rebate offer. Beyond approximately 67,000 units, a rival would be able to divert sales when the buyer is bound by an exclusive supply contract but not when it is the potential recipient of a target rebate.

Exclusive supply contracts raise antitrust concerns when they prevent a more efficient firm from entering an industry. ${ }^{234}$ They do so when they prevent such a firm from attaining minimum efficient scale. Impliedly, exclusive supply contracts raise antitrust concerns only to the extent that they could foreclose a sufficient share of the market to deny an entrant the possibility of operating at a minimum efficient scale, and the practical relevance of the possibility is disputed. ${ }^{235} \mathrm{~A}$ similar approach should be used regarding loyalty and fidelity rebates.

In most cases, neither exclusive supply contracts nor loyalty rebates will pose a foreclosure risk, because rivals can compete for the exclusive supply contract or offer a competing rebate bid when contracts are entered into or offers are extended. In an industry in which many suppliers enter such contracts or provide extensive loyalty rebates, the locus of competition may have moved from sales for particular units (analogous to sales of a commodity on the spot market) to competition for exclusive supply contracts or rebate relationships. ${ }^{236}$ Similarly, at the time at which a rebate is offered there is no obvious reason why rivals cannot compete by offering similar

234 This reflects at least a concern for the total surplus principle; in some cases successful lower cost firms may also sell at lower prices and hence meet the consumer surplus criterion as well.

235 See POSNER, supra note 39, at 230-34; Philippe Aghion \& Patrick Bolton, Contracts as a Barrier to Entry, 77 AM. ECON. ReV. 388, 388-89 (1987); Bruce H. Kobayashi, The Economics of Loyalty Discounts and Antitrust Law in the United States, 1 COMP. POL'Y INT'L 115, 128-46 (2005); llya R. Segal \& Michael D. Whinston, Naked Exclusion: Comment, 90 AM. ECON. REv. 296, 296-97 (2000); Christodoulos Stefanadis, Selective Contracts, Foreclosure, and the Chicago School View, 41 J.L. \& ECON. 429, 42934 (1998). Under one line of analysis, represented by Posner, where a dominant seller's use of exclusive supply contracts threatens to block entry by others, buyers will not sign an exclusive contract unless they are compensated by a price discount. If the situation is such that entry is likely to force a monopoly price down to a near competitive level, the discount that the seller must offer is likely to rise to a level that makes such contracting unprofitable. The alternative line of analysis asserts that a monopolist could find it profitable to share its monopoly profits with a critical number of buyers, preventing an entrant from attaining minimum efficient scale. But the information requirements of both scenarios are formidable.

236 Compare Appalachian Coals, Inc. v. United States, 288 U.S. 344, 362-63 (1933) (describing coal market production for orders for current use), with United States $v$ Gen. Dynamics Corp., 415 U.S. 486, 500-01 (1974) (describing production under long-term supply contracts). 
rebates or prices that have the same effect as the rebate. Viewed from the perspective of the locus of competition, many of the concerns expressed by European authorities about loyalty rebates disappear.

\section{Multiproduct Loyalty Rebates (Bundled Rebates)}

Although U.S. courts view single-product loyalty rebates with equanimity, they have become increasingly concerned with multiproduct rebates. Until recently, the leading U.S. case finding target rebates unlawful was the en banc decision of the Third Circuit in LePage's Inc. v. 3M ("LePage's Inc."). ${ }^{237}$

LePage's Inc. involved rebates offered by $3 \mathrm{M}$ to a number of large customers. 3M produces an array of products, including many different types of office products. It produces "Scotch" brand transparent tape, which is stocked by most office supply stores, and until the early 1990's held over $90 \%$ of the transparent tape market. During the early 1990's 3M also began selling private-label transparent tape. LePage's began to supply a line of transparent tape in 1980 to stores wanting their own "house" brand of tape and ultimately accounted for $88 \%$ of private-label transparent tape sales. In the middle to late 1990s, 3M began offering rebates to certain large retailers keyed to their meeting preselected sales targets. Because $3 \mathrm{M}$ was offering rebates computed on the aggregate sales of the several categories of goods purchased on which the customer attained targeted sales goals, these retailers felt significant pressure to meet the sales targets. The retailers, accordingly, diverted their orders on many office items, including transparent tape, to $3 \mathrm{M}$ in order to qualify for the maximum available rebate. As a result, LePage's claimed, customers seeking the $3 \mathrm{M}$ rebates were pressured to switch their transparent-tape orders from LePage's to $3 \mathrm{M}$ in order to qualify for the rebates. Since LePage's did not produce the wide product line that $3 \mathrm{M}$ produced, LePage's claimed that it would have had to match the total dollar rebate that $3 \mathrm{M}$ offered on a wide product line with a rebate solely on tape but in an equal dollar amount. This, LePage's claimed, it was unable to do.

The Third Circuit determined that 3M's target rebate program constituted a means by which $3 \mathrm{M}$ maintained its effective monopoly in transparent tape and thus constituted monopolization under $\$ 2$ of the Sherman Act. In so ruling, the court rejected 3M's contention that so long as its prices were above cost and thus not predatory, it could not violate the Sherman Act. The court failed to discuss, however, the

237324 F.3d 141 (3d Cir. 2003) (en banc), cert. denied, 542 U.S. 953 (2004). 
impact of 3M's pricing upon the particular market for transparent tape and discussed only its impact on particular buyers. If the entire discount over a buyer's purchases of several $3 \mathrm{M}$ products were allocated to transparent tape, would the result be that $3 \mathrm{M}$ was selling tape at prices below its marginal or average variable cost? If so, would that constitute predatory pricing? In a lengthy opinion of twenty-five pages, the court majority failed to address these questions.

More recently, the Ninth Circuit examined multiproduct bundled discounts with more care in Cascade Health Solutions v. Peacehealth ("Cascade Health"). ${ }^{238}$ Cascade Health involved two hospital providers in Lane County, Oregon. Cascade offered primary and secondary acute care in its only hospital. Peacehealth, which operated three hospitals, offered primary, secondary, and tertiary acute care. Peacehealth possessed a $75 \%$ market share in primary and secondary care services, a $90 \%$ share in tertiary neonatal services, and a $93 \%$ share of tertiary cardiovascular services. Cascade charged that Peacehealth attempted to monopolize by providing a lower reimbursement rate to health insurers that made Peacehealth their sole preferred provider than to health insurers that included both Peacehealth and Cascade as preferred providers. ${ }^{239}$ On appeal, the court set aside the jury verdict in favor of Cascade on the ground that the jury instructions were faulty. ${ }^{240}$

The Ninth Circuit adopted an approach to bundled discounts that drew from recommendations of the Antitrust Modernization Commission, but modified them in significant ways. ${ }^{241}$ That Commission's Report issued in April of 2007 criticized the Third Circuit's decision in LePage's Inc. for failing to articulate standards that would distinguish legitimate competitive pricing from pricing that was unlawfully exclusionary. ${ }^{242}$ The Commission then made a three-part recommendation for assessing the lawfulness of bundled rebates. ${ }^{243}$ First, the rebate over all products should be aggregated and applied to the product in issue. In LePage's Inc. this would require that the entire amount of the rebates on all sales to affected buyers be allocated to the sales of transparent tape. If, when so allocated, the defendant's price is below its incremental cost, the analysis proceeds to the next step. The second step analyzes whether the defendant is likely to recoup its losses on the product in question (as determined above). Third, if

\footnotetext{
238515 F.3d 883 (9th Cir. 2008).

239 Id. at $891-93$.

240 Id. at 911.

241 See generally ANTITRUST MOdERNIZATION COMM'N, supra note 11.

242 Id. at 97.

243 Id. at 99.
} 
recoupment is likely, there must be a further assessment as to whether the rebate program is likely to have an adverse effect on competition. If such an adverse effect is determined to be likely, the bundled rebate violates $\$ 2$ of the Sherman Act.

In Cascade Health, the Ninth Circuit accepted the Commission's first recommendation: aggregating the rebates and allocating the total of all of the rebates to the product in question, a technique that the court referred to as a "discount attribution" standard. ${ }^{244}$ If the price of that product, as reduced by the rebates, falls below an appropriate measure of incremental costs, the plaintiff has successfully established a necessary component of its case. ${ }^{245}$ The Ninth Circuit determined that an appropriate measure of incremental costs in this analysis is average variable cost. ${ }^{246}$ This approach, the Ninth Circuit explained, will bar rebates that carry the potential for excluding equally efficient rivals and are relatively easy for business firms to employ, because they need merely to compare the rebates that they are providing with their own average variable costs. ${ }^{247}$ Moreover, in the judgment of the court, applying the test is within the competence of the judiciary. ${ }^{248}$

The Ninth Circuit, however, rejected the Antitrust Modernization Commission's recommendation that the plaintiff establish the likelihood that the defendant would recoup its losses, and rejected that Commission's further recommendation that the plaintiff also establish the likelihood of a lessening of competition. The Ninth Circuit ruled that a likelihood of recoupment need not be shown, basing its holding on the ground that with multiproduct bundled rebates, predation can be established under the discount attribution standard, even though the defendant incurred no actual losses. The Ninth Circuit reasoned that if the defendant incurred no losses, there are no losses to recoup, and thus a recoupment requirement does not fit the method of determining liability.

The Ninth Circuit's position on this issue is unsound. Although a court may find that a defendant acted predatorily without having incurred actual losses, the defendant would have incurred losses in the form of opportunity costs, namely, the granting of the rebates reduced the revenues that the defendant would otherwise have earned. This conduct, therefore, is economically irrational unless it is an investment in a prospective monopoly that will generate future

\footnotetext{
${ }^{244}$ Cascade Health, 515 F.3d at 906.

245 Id. at 909.

246 Id. at 910 .

247 Id. at 907-08.

248 Id. at 908.
} 
revenues sufficient to compensate the defendant for this reduction in revenue. The Ninth Circuit, however, may have felt compelled to rule against a recoupment requirement on the ground that a defendant's need to recoup its losses would include losses whose calculation involved opportunity costs. The Ninth Circuit previously rejected opportunity costs as an element in predatory-pricing calculations. ${ }^{249}$ But the Ninth Circuit failed to recognize that the Antitrust Modernization Commission intended the recoupment requirement as a means for ensuring against false positives. ${ }^{250}$ By eliminating the recoupment requirement, the Ninth Circuit removed a critical check against a false determination of liability.

The Ninth Circuit also rejected the Commission's recommendation requiring that the plaintiff show that the bundled rebate program is likely to have an adverse effect on competition. ${ }^{251}$ The Commission's rationale for this requirement lay in its concern that bundled discounts should not be impeded unless they produced (or were likely to produce) an adverse effect on competition in the market. The Ninth Circuit rejected the Commission's recommendation on the grounds that the requirement was redundant because a private antitrust plaintiff must show a lessening of competition in the process of establishing standing. Although this part of the Ninth Circuit's analysis possesses a superficial appeal, it is also problematic. To establish standing in an antitrust case, a private plaintiff must demonstrate injury by the defendant's challenged conduct and that the injury is "of the type that the antitrust laws were intended to prevent and that flows from that which makes defendants' acts unlawful."252 This proof overlaps with proof on the merits that the defendant's conduct was unreasonable under the rule of reason.

Although analytically correct, the Ninth Circuit's ruling has broad ramifications for conceptualizing rule-of-reason cases. Under the Ninth Circuit's approach, in a rule-of-reason case there should be no separate requirement for proving the unreasonableness of the defendant's conduct, because the plaintiff will already have established that unreasonableness when it established its standing. This analysis does not apply to government-instituted suits, where the government

249 Rebel Oil Co. v. Atl. Richfield Co., 146 F.3d 1088, 1095 (9th Cir. 1998) ("[W]e agree that 'the use of opportunity costs [to show predatory pricing] must be held improper as a matter of law.' " (citing In re IBM Peripheral EDP Devices Antitrust Litig., 459 F. Supp. 626, 631 (N.D. Cal. 1978))).

250 See ANTITRUST MODERNIZATION COMM'N, supra note 11, at 99.

${ }^{251}$ Cascade Health, 515 F.3d at 910.

252 Brunswick Corp. v. Pueblo Bowl-O-Mat, 429 U.S. 477, 489 (1977). 
always has standing. In such suits, a showing of lessening of competition would have to be reincorporated into the elements of the offense, in bundled discount cases as well as all other rule-of-reason cases that the government may wish to bring. Whether the Ninth Circuit and other courts will collapse the substantive unreasonableness issue into the antitrust injury requirement in all private actions remains to be seen.

\section{PRICE DisCRIMINATION: AN OVERALl ASSESSMENT}

This Article argues that price discrimination is an important element in competition as well as regulation and does not deserve to be viewed with such suspicion. Some review may be in order to put price discrimination in the appropriate context.

Firms in perfect competition cannot engage in price discrimination, but they cannot sell differentiated products, either. When firms do sell differentiated products, they face downward sloping demand curves, which imply some discretion over price. That discretion may be used differentially across units sold, and across purchasers, yielding price discrimination. Yet profits may be only normal or even negative. This situation approximates the current predicament of the airline industry. Perhaps more frequently, firms in industries that might otherwise have quasi-collusive excess profits based on entry barriers and mutual dependence can be destabilized by the ability of participants to nibble at each other's markets through selective price competition rather than only charging prices such that no purchasers receive any better deal than any others. Finally, in some cases, firms may well use targeted discrimination to hinder the competitive progress of rivals who would benefit if they could not be singled out for special attack. This behavior can include certain fidelity rebates - the only category that deserves special scrutiny from competition authorities.

There is now consensus in the United States and the European Union that the appropriate goal of competition policy is some measure of social welfare. There is considerable dispute about whether that measure should be the maximization of consumer surplus or total surplus. ${ }^{253}$ Therefore, all rules and indices concerning price discrimination should be evaluated in relation to their likelihood to improve welfare by one or both of these criteria.

This Article suggests that price discrimination meets the total surplus test more often than the consumer surplus standard under monopoly. ${ }^{254}$

253 See Gifford \& Kudrle, supra note 109, at 426-27.

254 Cf. W. KiP VisCUSI ET AL., ECONOMICS OF REgULATION AND ANTITRUSt 269 (4th ed. 
Most output expanding discrimination passes the total surplus test, but not so with the consumer surplus standard. More specifically, seconddegree price discrimination almost always expands output but may well reduce consumer surplus. Alternatively, third-degree discrimination will necessarily reduce consumer surplus if output remains unchanged or is reduced because it generates increased profits. Total surplus is also reduced in such circumstances, however, because a new inefficiency is introduced by different marginal prices. Alternatively, some increase in output could overcome that inefficiency while still leaving consumers worse off as a group. When some markets are served only under discrimination, welfare may rise under both measures. In multiple-firm markets, some formal models based on fixed behavioral assumptions find reduced output when discrimination is introduced, but the most realistic models suggest that the permissibility of price discrimination changes firm behavior by increasing price competition and thereby increases welfare by both standards. ${ }^{255}$ The mere availability of price discrimination necessitates the use of a different, more competitive model.

Gloria Hurdle and Henry McFarland ${ }^{256}$ argue that price discrimination deserves attention parallel to entry and profitability as a likely indicator of a malfunctioning market. This Article, however, argues that there can be no single, infallible index of good market performance. Entry is neither sufficient nor necessary. Profitability, too, has its limitations; an inefficient firm of unremarkable profitability may sometimes succeed in blocking the entry or expansion of a rival with superior potential, but that is rare. Despite myriad problems of measurement, ${ }^{257}$ chronic excess profits (suitably corrected for risk), particularly for more than one incumbent firm, should be the premier indicator of competitive failure in any part of the economy. Whether some form of public intervention will improve such a situation is unclear, but price discrimination deserves no more special attention in the evaluation of a market than other elements of firm behavior.

2005) ("[D]iscrimination is not necessarily anti-competitive and, in fact, generally raises social welfare though perhaps benefiting firms at the cost of consumers.") These authors mean "inefficient" when they say "anticompetitive" because they employ an efficiency or total surplus standard.

255 See, e.g., Corts, supra note 65, at 220.

256 Gloria J. Hurdle \& Henry B. McFarland, Criteria for Identifying Market Power: A Comment on Baumol and Swanson, 70 ANTITRUST L.J. 687, 688 (2003).

257 Franklin M. Fisher \& John J. McGowan, On the Misuse of Accounting Rates of Return to Infer Monopoly Profits, 73 AM. ECON. REV. 82, 82 (1983). 
